\title{
Measuring Product Material Footprint as New Life Cycle Impact Assessment Method: Indicators and Abiotic Characterization Factors
}

\author{
Clemens Mostert * (D) and Stefan Bringezu $(\mathbb{D}$ \\ Center for Environmental Systems Research, University of Kassel, 34117 Kassel, Germany; \\ bringezu@uni-kassel.de \\ * Correspondence: mostert@uni-kassel.de
}

Received: 20 February 2019; Accepted: 28 March 2019; Published: 2 April 2019

check for updates

\begin{abstract}
The global economy is using growing amounts of natural resources such as raw materials, water, and land by making and using goods, services, and infrastructure. Aspirations on international, regional, and national levels e.g., the Sustainable Development Goals, the EU flagship initiative Roadmap to a Resource Efficient Europe or the German Program for Resource Efficiency are showing an urgent need to bring the global raw material use down to sustainable levels. An essential prerequisite to identify resource efficient options and to implement resource efficiency measures and solutions is the ability to compare different products or services regarding their raw material use. Until today, there is no internationally standardized approach defined and no software supported calculation method including the necessary data basis available to measure the raw material intensity of products. A new life cycle impact assessment (LCIA) method Product Material Footprint PMF is described. Two indicators are used to quantify the PMF: the Raw Material Input RMI and the Total Material Requirement TMR. The calculation of global median values for the characterization factors $\mathrm{CF}_{\mathrm{RMI}}$ and $\mathrm{CF}_{\mathrm{TMR}}$ of abiotic materials was done based on different databases. This article presents the methodological approach of the PMF, the calculation results for $\mathrm{CF}_{\mathrm{RMI}}$ of 42 abiotic materials and $\mathrm{CF}_{\mathrm{TMR}}$ of 36 abiotic materials, and the implementation of the LCIA method into the software openLCA for use with the ecoinvent database.
\end{abstract}

Keywords: product material footprint; new life cycle impact assessment method; abiotic materials; raw material input; total material requirement; characterization factors

\section{Introduction}

With the adoption of the United Nations 2030 Agenda for Sustainable Development, the Member States have agreed on 17 Sustainable Development Goals (SDGs) to promote activities of major importance for the planet [1]. For achieving the goals, an efficient and sustainable resource management is an essential prerequisite, since most of the SDGs have a direct or indirect relationship to the use of natural resources [2]. Of particular importance is target 12.2, which focuses on sustainable natural resource use measured by material productivity. Target 8.4 , which addresses the need for continuous improvement of resource efficiency, is already on the international agenda: G20, OECD, or EU have developed or are developing strategies to increase the efficient use of resources to limit the negative environmental and health impacts such as emissions, waste, land use, and water pollution [3-5]. Nevertheless, the efficient use and fair distribution of natural resources requires a holistic vision for a transformation toward a sustainable society and new forms of economic activity [6].

Natural resources "are material and non-material assets occurring in nature that were, at some point in time, deemed useful for humans" [7]. The global use of materials underwent an unprecedented 
growth in recent decades driven by the industrialization of emerging countries and the continuous growth in production and consumption of developed countries [8]. In contrast to climate protection, there are, so far, no internationally binding goals for the sustainable use of natural resources. The current use of material resources is around 90 billion tons per year and expected to double until 2050, which also entails a loss of natural eco-systems and biodiversity [9]. If a global level of raw material use of 50 billion tons is taken as the Safe Operating Space (SOS) and a world population of 10 billion people is expected in 2050, then the global consumption should not exceed 5 tons per capita and year [10]. For Germany, this would mean that the raw material consumption must be reduced by more than $75 \%$ within the next 30 years.

Resource productivity is already increasing in Germany. Fewer resources are needed for one unit of economic output [11]. The German Federal Government committed itself to doubling abiotic material productivity by 2020 based on the 1990 values in its national sustainability strategy [12]. Increasing resource productivity is also part of the German Green Growth Strategy and pays off economically since the development and application of efficiency technologies are creating new jobs and opening up new markets. With the adoption of the German Resource Efficiency Program ProgRess, it was decided to report on progress in the development of resource efficiency every four years [13]. Against this background, ProgRess II was published for which, in addition to abiotic material productivity, total raw material productivity is mentioned for the first time as an indicator [14]. While abiotic material productivity is based on abiotic Direct Material Input (DMI), the total raw material productivity relates to Raw Material Input (RMI), which are indicators based on economy-wide material flow accounting [15-17].

The growing need to increase resource productivity of economies requires us to measure the life cycle wide use of natural material resources both at the country as well as at the product level. Driven by the growing demand for robust indicators to measure resource use, progress has been made in harmonizing the methods for measuring the economy-wide material use [18]. The RMI and the derived Raw Material Consumption (RMC) have been most widely applied and results are available for most countries in the world [11]. Due to data availability, the calculation of Total Material Requirement (TMR) has been limited to selected countries such as China [19] even though the meaning of the TMR in terms of environmental impact must be regarded higher than of the RMI, which is economically defined as the produce of the primary sectors [20]. In contrast to the methods for measuring the economy wide material use, the ability to measure the material intensity of products or services is still in its infancy as a standardized approach and a reliable data basis are still missing.

A product requires an input of raw materials in all phases of its life cycle and, therefore, the cumulated raw material input determines its material intensity, which can be a multiple of its own mass. The Material Input per Service unit (MIPS) was the first concept that accounted for the cumulated primary material requirements without further specification of the associated bundle of environmental impacts [21]. Saurat and Ritthoff provided an overview of methods and tools to determine the MIPS and demonstrated an advanced calculation method [22]. The life cycle wide primary raw material input for a product or service can be referred to as the material footprint [23] and its use as a sum parameter in LCA has already been proposed [24]. Its calculation, based on the Cumulated Raw Material Demand CRD, underwent a standardization process in Germany and is described in a recently published guideline [25]. For the abiotic components, the CRD and the RMI are identically defined.

Life cycle impact assessment (LCIA) methods were originally developed for measuring environmental impacts based on output-oriented indicators, which are calculated by Characterization Factors (CF) assigned to elementary flows. Most prominent is the carbon footprint, where the Global Warming Impact (GWI), which is often referred to as Global Warming Potential GWP, is calculated by the characterization factors (GWP) of greenhouse gases assigned to their mass flows. This article presents the Product Material Footprint (PMF) as a new LCIA method based on two input oriented indicators RMI and TMR. The indicators are calculated by assigning defined Characterization Factors Raw Material Input $\mathrm{CF}_{\mathrm{RMI}}$ and Characterization Factors Total Material Requirement $\mathrm{CF}_{\mathrm{TMR}}$ to the 
mass flows of the materials that are required as a life cycle wide input for the product or service. The calculation is done analogously to the Cumulated Energy Demand CED by adding different energy sources in terms of their energy equivalents $[26,27]$. Global median values for $\mathrm{CF}_{\mathrm{RMI}}$ and $\mathrm{CF}_{\mathrm{TMR}}$ were calculated for different abiotic materials with a focus on metals, non-metallic minerals, and fossil energetic materials using different databases. For the first time, these procedures were implemented into the software openLCA (version 1.7) for use with the ecoinvent database (version 3.1, cut-off LCI) as a new LCIA method and used for the software-supported calculation of the material intensity of products and services.

\section{Methodological Approach}

\subsection{LCIA Method and Characterization Model}

The PMF is proposed as a new input oriented LCIA method that fulfills the requirements and necessary components described in ISO 14044 [28]. The method is applied for a software-supported calculation of RMI and TMR per Functional Unit (FU) based on the material input as the LCI result and the assigned $\mathrm{CF}_{\mathrm{RMI}}$ and $\mathrm{CF}_{\mathrm{TMR}}$. The extraction of primary materials from the ecosphere and the transfer of raw materials like metal ores, non-metallic minerals, fossil energetic raw materials, and biomass into the technosphere is considered as the impact category and the natural environment as the area of protection (AoP). According to ISO 14044, a characterization model should be scientifically valid and based upon a distinct identifiable environmental mechanism [28]. The loss in life supporting services of the extracted materials and the environmental impacts of mining and beneficiation as well as the further processing in manufacturing during the use phase are quite diverse and vary according to local conditions, materials, and process technologies. Nevertheless, some basic causal relationships can be observed to characterize the type of impacts.

(A) The total extraction of primary materials usually leads to the loss of the in-situ life supporting functions and services of the extracted and translocated material and the affected landscapes, including cleared vegetation and changes in hydrology, consequently to a local to regional change and often to a damage of the natural environment as an endpoint around the location of the extraction. As a midpoint indicator, total extraction of primary materials associated with the life cycle of products and services is measured by the TMR.

(B) Furthermore, the extraction process determines the amount of raw materials that is further processed and used in production and consumption, the volume of final emissions and waste, and the associated bundle of environmental impacts on land, water, and air, which will subsequently-and additionally to (A) - occur at other places distant from the location of extraction. As a midpoint indicator, the RMI, measures the life-cycle wide cumulative amount of used extraction of raw materials.

Measuring the mass turnover of primary material extraction (A) and raw material extraction (B) accounts for basic determinants of environmental impact potentials. The method provides quantitative information on the sustainability of the product system in terms of efficient use of primary and raw materials as a proxy for the potential environmental damage to nature from the location of extraction to final disposal. The PMF and its indicators can be interpreted as measures of a generic environmental pressure associated with the life-cycle wide cumulative mass turnover of natural material extraction, translocation, and use [20].

Since every product system requires an input of material, energy, water, and land, all four footprints should be considered to get mostly sufficient information about the environmental impact potential [29] and to avoid trade-offs in the search for alternative solutions.

\subsection{Calculation of Indicators}

The characterization models for the carbon footprint based on the characterization factor GWP has been used in a great number of LCA and is widely accepted. The characterization model for the PMF, as an accounting for the material intensity of products or services, should consider the life-cycle 
wide input of raw materials as well as the total amount of primary material extracted. Therefore, two indicators are used to quantify the PMF: the Raw Material Input RMI and the Total Material Requirement TMR. The loss in supporting services of the extracted materials and the environmental impacts of mining and beneficiation are quite diverse and vary, according to materials and extraction processes. However, the mass of the material, which is used as an input into the product system, is always only a fraction of the extracted raw material. The lower the fraction, the higher the amount of extracted raw material is and the higher the loss in supporting functions and services is. Therefore, the RMI, measuring the total amount of raw materials that is extracted from nature and transferred into the technosphere, i.e., used extraction, is a proxy for the potential damage to the natural environment. The RMI per functional unit FU is calculated using the equation below.

$$
\mathrm{RMI}=\sum_{\mathrm{i}=1}^{\mathrm{n}} \mathrm{m}_{\text {material i }} \times \mathrm{CF}_{\mathrm{RMI}_{\text {material }}}
$$

The RMI is the raw material input measured in $\mathrm{kg}$ raw material per $\mathrm{FU}, \mathrm{m}_{\text {material } \mathrm{i}}$ is the mass of material i measured in $\mathrm{kg}$ per $\mathrm{FU}, \mathrm{n}$ is the total number of different materials required for the provision

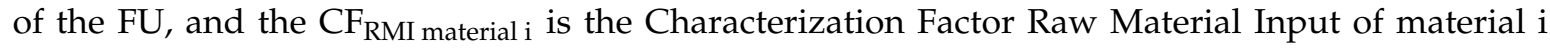
measured in $\mathrm{kg}$ raw material per $\mathrm{kg}$ material.

The TMR is also used as an indicator, which measures the total amount of extracted primary material, so the material that is extracted to get access to the raw material remains in the ecosphere i.e., unused extraction. The TMR per FU is calculated using the equation below.

$$
\mathrm{TMR}=\sum_{\mathrm{i}=1}^{\mathrm{n}} \mathrm{m}_{\text {material i }} \times \mathrm{CF}_{\mathrm{TMR}_{\text {material }}}
$$

The TMR is the total material requirement measured in $\mathrm{kg}$ primary material per $\mathrm{FU}, \mathrm{m}_{\text {material }} \mathrm{i}$ is the mass of material i measured in $\mathrm{kg}$ per $\mathrm{FU}, \mathrm{n}$ is the total number of different materials required for the provision of the $\mathrm{FU}$, and the $\mathrm{CF}_{\mathrm{TMR}}$ material i is the Characterization Factor Total Material Requirement of material i measured in $\mathrm{kg}$ primary material per $\mathrm{kg}$ material.

The RMI and the TMR are categorized by the material flows they are accounting for: the RMI accounts for used extractions from the environment, covering all raw materials that are sold by mining, agriculture, forestry, and fisheries. Therefore, the RMI is the sum of all abiotic and biotic raw materials, which represent an input into the product over its complete life cycle.

$$
\mathrm{RMI}=\mathrm{RMI}_{\mathrm{abiotic}}+\mathrm{RMI}_{\text {biotic }}
$$

The TMR considers both used and unused extraction. The unused extraction includes all natural material that is moved and dumped to enable the extraction of the raw material. The TMR measures the total amount of abiotic and biotic primary material required over the complete life cycle of a product.

$$
\mathrm{TMR}=\mathrm{TMR}_{\mathrm{abiotic}}+\mathrm{TMR}_{\text {biotic }}
$$

Thus, the TMR reflects the life cycle wide requirement of primary materials and the RMI of the life cycle wide input of raw materials for a product or service. The difference between the TMR and the RMI represents the unused extraction. The abiotic and biotic parts of both indicators should be calculated and reported separately because they are linked to different environmental impacts [10].

\subsection{Calculation of Characterization Factors}

The calculation of the $\mathrm{CF}_{\mathrm{RMI}}$ and $\mathrm{CF}_{\mathrm{TMR}}$ is based on the MIPS concept of Schmidt-Bleek and a further development of MIPS 2.0, which generates CF assigned to elementary flows of the ecoinvent database to calculate the input of natural resources as raw materials, water, and air [22,30]. The 
calculation of the raw material input in MIPS 2.0 has some methodological weaknesses and limitations: (1) It applies mass allocation instead of economic allocation for multi-metal ores. (2) It was developed for ecoinvent version 2.2 and has not been updated for ecoinvent version 3. (3) The data for calculation of the CF are solely based on information from the elementary flows "resource, in ground" of the ecoinvent database, which defines the flows of abiotic material from nature to the technosphere. However, these elementary flows were not developed for mass balanced calculation. Some flow descriptions contain information on the material concentration in the raw material. The update of LCI methods to account for different ore grades has been suggested [31], but, so far, the information are only available for a limited number of materials and mostly outdated e.g., ore grades for copper are based on data from the year 1994 [32]. The calculation and the use of updated world median values for the $\mathrm{CF}$ was proposed mainly to overcome further problems in the calculation using the ecoinvent database e.g., the limited number of elementary flows [33].

The $\mathrm{CF}_{\mathrm{RMI}}$ material i can be defined as the ratio of the mass of the extracted raw material i.e., used extraction and the mass of the material $i$ in the extracted raw material.

$$
\mathrm{CF}_{\mathrm{RMI}_{\text {material } \mathrm{i}}}=\frac{\mathrm{m}_{\text {extracted raw material }}}{\mathrm{m}_{\text {material } \mathrm{i} \text { in extracted raw material }}}
$$

The $\mathrm{CF}_{\mathrm{RMI}}$ material $\mathrm{i}$ can be also calculated by the concentration of the material $\mathrm{i}$ in the extracted raw material, e.g., the metal concentration in the extracted ore.

$$
\mathrm{CF}_{\mathrm{RMI}_{\text {material i }}}=\frac{1}{\mathrm{C}_{\text {material i in extracted raw material }}}
$$

The $\mathrm{CF}_{\mathrm{TMR}}$ material i is calculated below.

$$
\mathrm{CF}_{\mathrm{TMR}_{\text {material i }}}=\mathrm{CF}_{\mathrm{RMI}_{\text {material i }}} \times\left(1+\text { coeff }_{\text {extraction material i }}\right)
$$

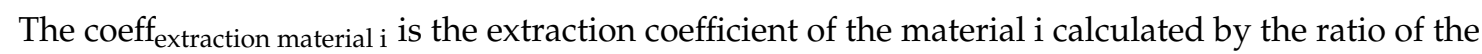
mass of the unused extraction and the mass of the extracted primary material for production of the material measured in $\mathrm{kg}$ per $\mathrm{kg}$.

$$
\text { coeff }_{\text {extraction material } \mathrm{i}}=\frac{\mathrm{m}_{\text {unused extraction }}}{\mathrm{m}_{\text {extracted primary material for production of material } \mathrm{i}}}
$$

For quantification of the $\mathrm{CF}_{\mathrm{RMI} \text { materiali }}$, allocation has to be considered if the extracted raw material contains more than one material. For example, metallic minerals are extracted in mines with single-metal ores (SMO) but also with multiple-metal ores (MMO). For SMO, the total mass of the extracted mineral is attributed only to one metal and, therefore, the allocation factor $\mathrm{AF}_{\text {material }}$ is equal to one. For MMO, the total mass of the extracted minerals has to be distributed to all metals that are produced from the mine. In this case, the $\mathrm{AF}_{\text {material } i}$ for each metal is greater than zero and less than one and the sum of all $\mathrm{AF}$ for a specific mine is equal to one. Economic allocation should be applied when the mineral is extracted and further processed with the aim to sell every single material according to the market value [34]. In particular, for metal mining, the value of extraction and the amount of metals produced may differ considerably depending on the price of the metal, which ultimately determines the purpose of the processes. The $\mathrm{AF}_{\text {material }}$ is calculated using the formula below.

$$
\mathrm{AF}_{\text {material } \mathrm{i}}=\frac{\mathrm{c}_{\text {material } \mathrm{i}} \times \mathrm{AP}_{\text {material } \mathrm{i}}}{\sum_{\mathrm{j}=1}^{\mathrm{m}} \mathrm{c}_{\text {material }_{\mathrm{j}}} \times \mathrm{AP}_{\text {material }_{\mathrm{j}}}}
$$

The $c_{\text {material }} \mathrm{i}$ is the concentration of the material $\mathrm{i}$ in the extracted raw material, e.g., the ore, measured in percent, $\mathrm{m}$ is the total number of different materials in the extracted raw material, and $\mathrm{AP}_{\text {material } \mathrm{j}}$ is the average market price of the material $\mathrm{j}$ measured in monetary units. For economic allocation, a 10-year average market price should be considered [35]. 


\subsection{Data Sources}

Three different data sources were used to calculate the global median values for the $\mathrm{CF}_{\mathrm{RMI}}$. The results are applied in the described order due to higher global coverage and timeliness of the data. The data sources are: (1) the database of the former Raw Materials Group (RMG) [36], (2) a database taken from an IFEU report [34], and (3) the ecoinvent database (version 3.1).

The values for the $\mathrm{CF}_{\mathrm{RMI}}$ of 10 metals were calculated using the RMG database, which provides information on the global mining sector and the associated data includes information on yearly production quantities of minerals and metal ore concentrations in each mine. From the mine specific allocation factor $\mathrm{AF}_{\text {material i mine }}$ the $\mathrm{CF}_{\mathrm{RMI}}$ material i mine was calculated. The World Bank commodity price data were used to calculate the 10-year average market price of the materials [37]. The mines were sorted by the $\mathrm{CF}_{\mathrm{RMI}}$ material i mine and the allocated production volumes were cumulated to identify the mine with the median ton of global production. This mine represents the global median $\mathrm{CF}_{\mathrm{RMI}}$ of material i. As an example, the values for the $\mathrm{CF}_{\mathrm{RMI}}$ copper mine over the allocated cumulative raw material production of 141 considered mines including the median value and the 25th and 75th percentile are shown in Figure 1.

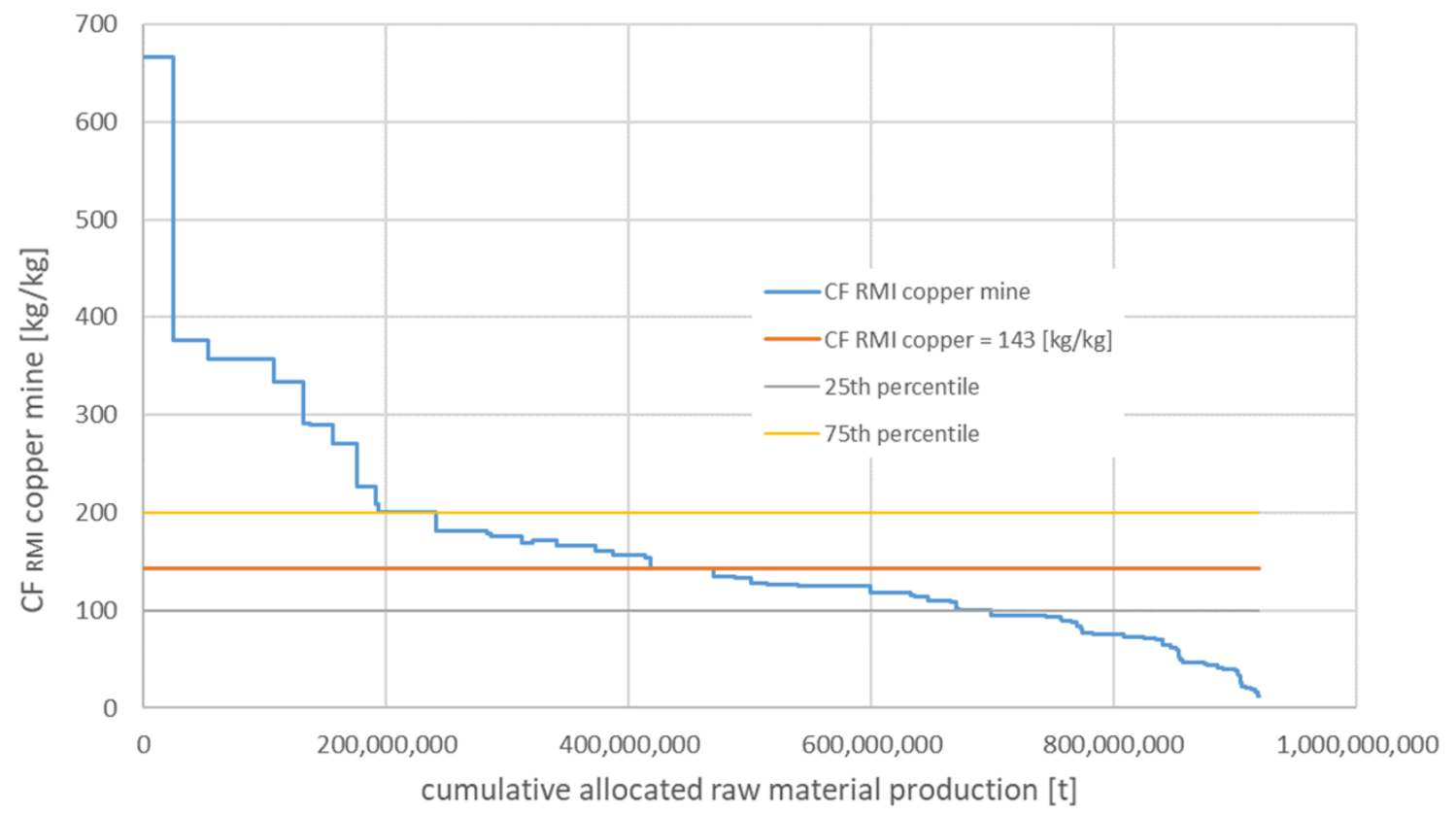

Figure 1. The values for the Characterization Factor Raw Material Input for copper per mine $\mathrm{CF}_{\mathrm{RMI}}$ copper mine and the median value as well as the 25 th and 75 th percentile over the cumulative allocated raw material production of 141 copper mines [36].

The global average values for the $\mathrm{CF}_{\mathrm{RMI}}$ of 11 other metals were calculated from the database taken from the IFEU report. The report presents an approach for converting product flows into raw material equivalents RME and the underlying data [34]. The data refer to the year 2010 and are taken from annual reports of global mining companies and from the United States Geological Survey (USGS). The $\mathrm{CF}_{\mathrm{RMI}}$ of 21 additional materials were calculated from the ecoinvent database. So far, LCA databases do not provide explicit data, which can be used to calculate the $\mathrm{CF}_{\mathrm{RMI}}$ and $\mathrm{CF}_{\mathrm{TMR}}$. In the description of some elementary flows, in particular, "resource, in ground", the concentration of the material in the raw material is given, e.g., "Barite, $15 \%$ in crude ore, in ground." Using Equation (6) the $\mathrm{CF}_{\mathrm{RMI}}$ barite is resulting in $6.7 \mathrm{~kg} / \mathrm{kg}$. If a material is defined by elementary flows with different concentrations of the material in the raw material, the median value was applied.

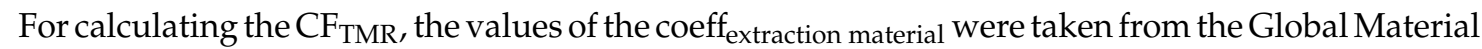
Flows (GMF) database (version May 2016). This database provides data for the coeff extraction material on 
the basis of 45,726 data points from 38 different data sources, but is no longer updated [38]. The GMF database covers data on biomass, fossil fuels, minerals, and metals for 203 countries. From these data,

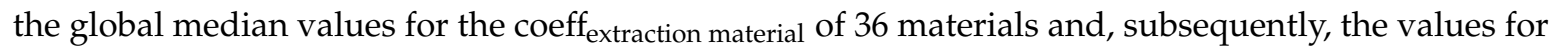
the CF TMR were calculated (compare Equation (7)).

\section{Results}

\subsection{Values for the Characterization Factor Raw Material Input $C F_{R M I}$}

Table 1 shows the values for the $\mathrm{CF}_{\mathrm{RMI}}$ of 10 metals calculated using data from the RMG database [36]: Chromium (Cr), Cobalt (Co), Copper (Cu), Gold (Ag), Iron (Fe), Lead (Pb), Molybdenum (Mo), Nickel (Ni), Silver (Ag), and Zinc (Zn).

Table 1. Values for the Characterization Factor Raw Material Input CF RMI of 10 metals calculated with data from the RMG database [36].

\begin{tabular}{cccccc}
\hline Material & Chromium (Cr) & Cobalt (Co) & Copper (Cu) & Gold (Ag) & Iron (Fe) \\
\hline $\mathrm{CF}_{\mathrm{RMI}}[\mathrm{kg} / \mathrm{kg}]$ & 2.7 & 115 & 143 & 943,610 & 2.7 \\
\hline Material & Lead $\mathbf{( P b )}$ & Molybdenum (Mo) & Nickel (Ni) & Silver (Ag) & Zinc (Zn) \\
\hline $\mathrm{CF}_{\mathrm{RMI}}[\mathrm{kg} / \mathrm{kg}]$ & 12 & 981 & 63 & 10,561 & 13 \\
\hline
\end{tabular}

Table 2 shows the values for the $\mathrm{CF}_{\mathrm{RMI}}$ of 11 metals calculated from the database of the IFEU report [34]: Aluminium (Al), Cadmium (Cd), Magnesium (Mg), Manganese (Mn), Palladium (Pd), Platinum (Pt), Rhodium (Rh), Tantalum (Ta), Tin (Sn), Titanium (Ti), and Zirconium (Zr).

Table 2. Values for the Characterization Factor Raw Material Input $\mathrm{CF}_{\mathrm{RMI}}$ of 11 metals calculated with data from the database of the IFEU report [34].

\begin{tabular}{ccccccc}
\hline Material & $\begin{array}{c}\text { Aluminium } \\
(\mathbf{A l})\end{array}$ & $\begin{array}{c}\text { Cadmium } \\
(\mathbf{C d})\end{array}$ & $\begin{array}{c}\text { Magnesium } \\
\mathbf{( M g})\end{array}$ & $\begin{array}{c}\text { Manganese } \\
(\mathbf{M n})\end{array}$ & $\begin{array}{c}\text { Palladium } \\
\mathbf{( P d})\end{array}$ & $\begin{array}{c}\text { Platinum } \\
(\mathbf{P t})\end{array}$ \\
\hline $\begin{array}{c}\mathrm{C} F_{\mathrm{RMI}} \\
{[\mathrm{kg} / \mathrm{kg}]}\end{array}$ & 5.3 & 735 & 7.8 & 2.8 & 66,063 & 274,186 \\
\hline Material & $\begin{array}{c}\text { Rhodium } \\
(\mathbf{R h})\end{array}$ & $\begin{array}{c}\text { Tantalum } \\
\mathbf{( T a})\end{array}$ & $\begin{array}{c}\text { Tin } \\
\mathbf{( S n )}\end{array}$ & $\begin{array}{c}\text { Titanium } \\
\mathbf{( T i )}\end{array}$ & $\begin{array}{c}\text { Zirconium } \\
\mathbf{( Z r )}\end{array}$ & \\
\hline $\begin{array}{c}\mathrm{CF} F_{\mathrm{RMI}} \\
{[\mathrm{kg} / \mathrm{kg}]}\end{array}$ & 520,571 & 6105 & 415 & 61 & 53 & \\
\hline
\end{tabular}

Table 3 shows the values for the $\mathrm{CF}_{\mathrm{RMI}}$ of 21 materials calculated from data of the ecoinvent database (version 3.1, cut-off LCI): Barite (Ba), Cerium (Cer), Europium (Eu), Fluorine (F), Fluorspar $\left(\mathrm{CaF}_{2}\right)$, Gadolinium (Gd), Gallium (Ga), Indium (In), Kaolinite $\left(\mathrm{Al}_{4}\right)$, Kieserite $\left(\mathrm{Mg}\left[\mathrm{SO}_{4}\right] \cdot \mathrm{H}_{2} \mathrm{O}\right)$, Lanthanum (La), Lithium (Li), Magnesite $\left(\mathrm{MgCO}_{3}\right)$, Neodymium (Nd), Phosphorus (P), Praseodymium (Pr), Samarium $(\mathrm{Sm})$, Sylvite $(\mathrm{KCl})$, Tellurium $(\mathrm{Te})$, Titania $\left(\mathrm{TiO}_{2}\right)$, and Uranium $(\mathrm{U})$. 
Table 3. Values for the Characterization Factor Raw Material Input $\mathrm{CF}_{\mathrm{RMI}}$ of 21 abiotic materials calculated from the ecoinvent database (version 3.1, cut-off LCI).

\begin{tabular}{|c|c|c|c|c|c|c|c|}
\hline Material & $\begin{array}{l}\text { Barite } \\
\text { (Ba) }\end{array}$ & $\begin{array}{l}\text { Cerium } \\
\text { (Cer) }\end{array}$ & $\begin{array}{l}\text { Europium } \\
\quad(\mathrm{Eu})\end{array}$ & $\begin{array}{l}\text { Fluorine } \\
\text { (F) }\end{array}$ & $\begin{array}{c}\text { Fluorspar } \\
\left(\mathrm{CaF}_{2}\right)\end{array}$ & $\begin{array}{l}\text { Gadolinum } \\
\text { (Gd) }\end{array}$ & $\begin{array}{l}\text { Gallium } \\
\text { (Ga) }\end{array}$ \\
\hline $\begin{array}{l}\mathrm{CF}_{\mathrm{RMI}} \\
{[\mathrm{kg} / \mathrm{kg}]}\end{array}$ & 6.7 & 42 & 16,667 & 67 & 1.1 & 6667 & 7143 \\
\hline Material & $\begin{array}{l}\text { Indium } \\
\text { (In) }\end{array}$ & $\begin{array}{c}\text { Kaolinite } \\
\left(\mathrm{Al}_{4}\right)\end{array}$ & $\begin{array}{c}\text { Kieserite } \\
\left(\mathrm{Mg}\left[\mathrm{SO}_{4}\right] \cdot \mathrm{H}_{2} \mathrm{O}\right) \\
\end{array}$ & $\begin{array}{l}\text { Lanthanum } \\
\text { (La) }\end{array}$ & $\begin{array}{l}\text { Lithium } \\
\quad \text { (Li) }\end{array}$ & $\begin{array}{c}\text { Magnesite } \\
\left(\mathrm{MgCO}_{3}\right)\end{array}$ & $\begin{array}{l}\text { Neodymium } \\
\text { (Nd) }\end{array}$ \\
\hline $\begin{array}{c}\mathrm{CF}_{\mathrm{RMI}} \\
{[\mathrm{kg} / \mathrm{kg}]} \\
\end{array}$ & 3334 & 4.2 & 4 & 139 & 667 & 1.7 & 250 \\
\hline Material & $\begin{array}{l}\text { Phosphorus } \\
\text { (P) }\end{array}$ & $\begin{array}{l}\text { Praseodymium } \\
\text { (Pr) }\end{array}$ & $\begin{array}{l}\text { Samarium } \\
\text { (Sa) }\end{array}$ & $\begin{array}{l}\text { Sylvite } \\
\text { (KCl) }\end{array}$ & $\begin{array}{l}\text { Tellurium } \\
\text { (Te) }\end{array}$ & $\begin{array}{l}\text { Titania } \\
\left(\mathrm{TiO}_{2}\right)\end{array}$ & $\begin{array}{l}\text { Uranium } \\
\text { (U) }\end{array}$ \\
\hline $\begin{array}{c}\mathrm{CF}_{\mathrm{RMI}} \\
{[\mathrm{kg} / \mathrm{kg}]}\end{array}$ & 17 & 2381 & 3333 & 4 & $5,000,000$ & 98 & 1000 \\
\hline
\end{tabular}

\subsection{Values for the Characterization Factor Total Material Requirement $C F_{T M R}$}

Table 4 shows the values for the $\mathrm{CF}_{\mathrm{TMR}}$ of 36 abiotic materials calculated using the GMF database [38]: Aluminium (Al), Anhydrite $\left(\mathrm{CaSO}_{4}\right)$, Barite (Ba), Basalt, Borax $\left(\mathrm{Na}_{2} \cdot 8 \mathrm{H}_{2} \mathrm{O}\right)$, Chromium $(\mathrm{Cr})$, Clay, Coal, brown, Coal, hard, Copper $(\mathrm{Cu})$, Diatomite $\left(\mathrm{SiO}_{2}\right)$, Dolomite, Feldspar, Fluorspar $\left(\mathrm{CaF}_{2}\right)$, Gold (Ag), Granite, Gravel, Gypsum $\left(\mathrm{CaSO}_{4} \cdot 2 \mathrm{H}_{2} \mathrm{O}\right)$, Iron (Fe), Kaolinite $\left(\mathrm{Al}_{4}[\mathrm{OH}]_{8} \mathrm{Si}_{4} \mathrm{O}_{10}\right)$, Lead ( $\mathrm{Pb})$, Manganese (Mn), Molybdenum (Mo), Nickel (Ni), Oil, crude, Palladium (Pd), Phosphorus $(\mathrm{P})$, Platinum (Pt), Rhodium (Rh), Silver (Ag), Steatite, Talc, Tin ( $\mathrm{Sn})$, Titania $\left(\mathrm{TiO}_{2}\right)$, Uranium (U), and Zinc (Zn).

Table 4. Values for the Characterization Factor Total Material Requirement $\mathrm{CF}_{\mathrm{TMR}}$ of 36 abiotic materials calculated from the Global Material Flows (GMF) database [38].

\begin{tabular}{|c|c|c|c|c|c|c|}
\hline Material & $\begin{array}{l}\text { Aluminium } \\
\text { (Al) }\end{array}$ & $\begin{array}{l}\text { Anhydrite } \\
\left(\mathrm{CaSO}_{4}\right)\end{array}$ & $\begin{array}{c}\text { Barite } \\
\text { (Ba) }\end{array}$ & Basalt & $\begin{array}{c}\text { Borax } \\
\left(\mathrm{Na}_{2} \cdot 8 \mathrm{H}_{2} \mathrm{O}\right)\end{array}$ & $\begin{array}{l}\text { Chromium } \\
\text { (Cr) }\end{array}$ \\
\hline $\begin{array}{l}\mathrm{CF}_{\mathrm{TMR}} \\
{[\mathrm{kg} / \mathrm{kg}]}\end{array}$ & 11 & 1.1 & 11 & 1.01 & 1.1 & 5.9 \\
\hline Material & Clay & Coal, Brown & Coal, Hard & $\begin{array}{l}\text { Copper } \\
(\mathbf{C u})\end{array}$ & $\begin{array}{l}\text { Diatomite } \\
\left(\mathrm{SiO}_{2}\right)\end{array}$ & Dolomite \\
\hline $\begin{array}{l}\mathrm{CF}_{\mathrm{TMR}} \\
{[\mathrm{kg} / \mathrm{kg}]}\end{array}$ & 2.3 & 1.3 & 1.2 & 157 & 1.1 & 1.01 \\
\hline Material & Feldspar & $\begin{array}{l}\text { Flourspar } \\
\left(\mathrm{CaF}_{2}\right)\end{array}$ & $\begin{array}{l}\text { Gold } \\
\text { (Au) }\end{array}$ & Granite & Gravel & $\begin{array}{c}\text { Gypsum } \\
\left(\mathrm{CaSO}_{4} \cdot 2 \mathrm{H}_{2} \mathrm{O}\right)\end{array}$ \\
\hline $\begin{array}{l}\mathrm{CF}_{\mathrm{TMR}} \\
{[\mathrm{kg} / \mathrm{kg}]}\end{array}$ & 1.1 & 1.4 & $2,906,319$ & 1.01 & 1.01 & 1.04 \\
\hline Material & Iron $(\mathrm{Fe})$ & $\begin{array}{c}\text { Kaolinite } \\
\left(\mathrm{Al}_{4}[\mathrm{OH}]_{8} \mathrm{Si}_{4} \mathrm{O}_{10}\right)\end{array}$ & $\begin{array}{l}\text { Lead } \\
(\mathrm{Pb})\end{array}$ & $\begin{array}{l}\text { Manganese } \\
\text { (Mn) }\end{array}$ & $\begin{array}{l}\text { Molybdenum } \\
\text { (Mo) }\end{array}$ & $\begin{array}{l}\text { Nickel } \\
\text { (Ni) }\end{array}$ \\
\hline $\begin{array}{l}\mathrm{CF}_{\mathrm{TMR}} \\
{[\mathrm{kg} / \mathrm{kg}]}\end{array}$ & 5.1 & 6.3 & 15 & 7.1 & 1854 & 101 \\
\hline Material & Oil, Crude & $\begin{array}{l}\text { Palladium } \\
\quad \text { (Pd) }\end{array}$ & $\begin{array}{l}\text { Phosphorus } \\
\text { (P) }\end{array}$ & $\begin{array}{l}\text { Platinum } \\
\quad(P t)\end{array}$ & $\begin{array}{l}\text { Rhodium } \\
\text { (Rh) }\end{array}$ & $\begin{array}{l}\text { Silver } \\
\text { (Ag) }\end{array}$ \\
\hline $\begin{array}{l}\mathrm{CF}_{\mathrm{TMR}} \\
{[\mathrm{kg} / \mathrm{kg}]}\end{array}$ & 1.2 & 107,683 & 75 & 445,826 & 572,628 & 17,954 \\
\hline Material & Steatite & Talc & $\begin{array}{l}\text { Tin } \\
(\mathrm{Sn})\end{array}$ & $\begin{array}{l}\text { Titania } \\
\left(\mathrm{TiO}_{2}\right)\end{array}$ & $\begin{array}{l}\text { Uranium } \\
\text { (U) }\end{array}$ & $\begin{array}{l}\text { Zinc } \\
(Z n)\end{array}$ \\
\hline $\begin{array}{l}\mathrm{CF}_{\mathrm{TMR}} \\
{[\mathrm{kg} / \mathrm{kg}]}\end{array}$ & 2 & 1.1 & 502 & 98 & 17,000 & 16 \\
\hline
\end{tabular}




\subsection{Software Implementation}

The LCIA method PMF is implemented into the software openLCA (version 1.7) based on the calculated CF using the ecoinvent database (version 3.1, cut-off LCI). In this LCA software solution, new impact assessment methods can be created by adding new impact categories and impact factors and by assigning each elementary flow of the database to the impact factors with a CF [39]. The PMF was set up in openLCA by adding the impact categories Abiotic Raw Material Input and Abiotic Total Material Requirement and the impact factors $\mathrm{RMI}_{\mathrm{abiotic}}$ and $\mathrm{TMR}_{\mathrm{abiotic}}$.

The values of the $\mathrm{CF}_{\mathrm{RMI}}$ and $\mathrm{CF}_{\mathrm{TMR}}$ are assigned to the 143 elementary flows "resource, in ground" of the ecoinvent database. The elementary flows refer to 78 different materials since some materials are described by different elementary flows, e.g., copper by 12 elementary flows. The $\mathrm{CF}_{\mathrm{RMI}}$ calculated from the RMG database are assigned to 59 elementary flows, calculated from the IFEU database to 11 elementary flows, and calculated from the ecoinvent database to 26 elementary flows. For 36 materials or 42 elementary flows, no values for the $\mathrm{CF}_{\mathrm{RMI}}$ could be calculated. For these materials, the $\mathrm{CF}_{\mathrm{RMI}}$ is set to one, considering the own mass. In total, five elementary flows "resources, in ground" of the ecoinvent database are identified as not being flows of abiotic material. For these elementary flows, the $\mathrm{CF}_{\mathrm{RMI}}$ is set to zero. Figure 2 shows the share of elementary flows "resource, in ground" of the ecoinvent database (version 3.1, cut-off LCI) for which the values of the Characterization Factor Raw Material Input $\mathrm{CF}_{\mathrm{RMI}}$ are assigned according to data sources and assumptions.

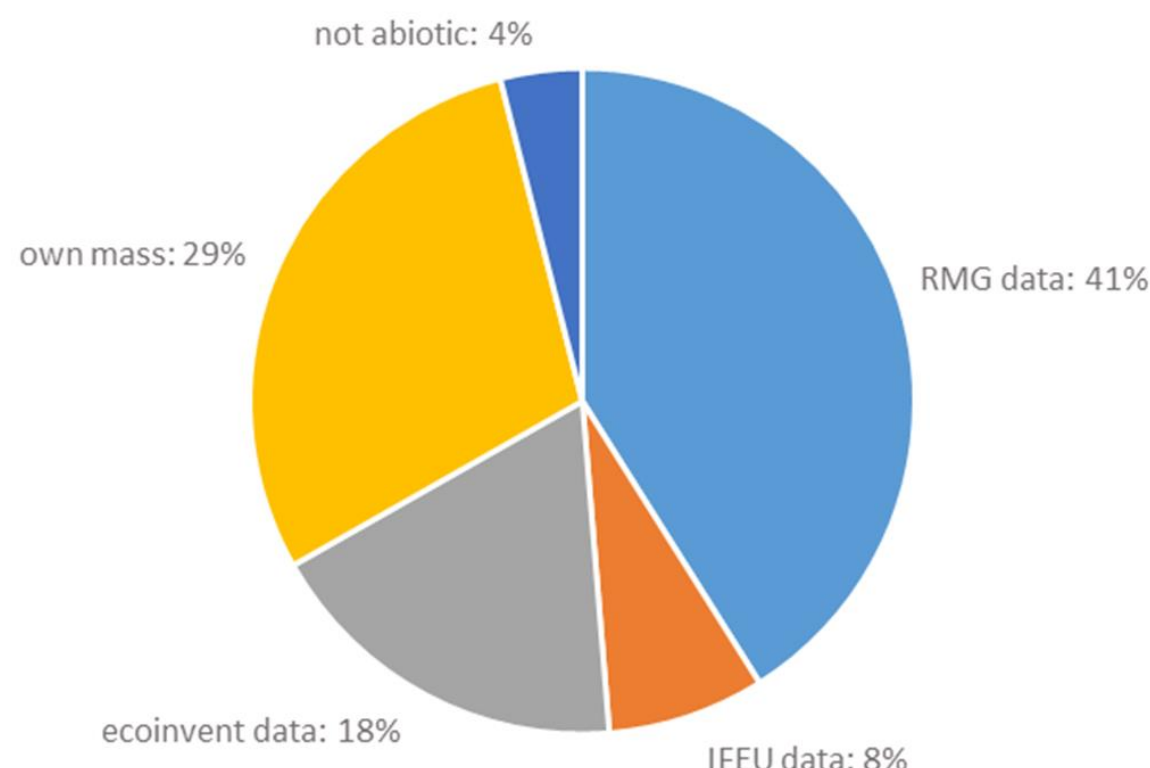

Figure 2. Share of elementary flows "resource, in ground" of the ecoinvent database (version 3.1, cut-off LCI) for which the values of the Characterization Factor Raw Material Input $\mathrm{CF}_{\mathrm{RMI}}$ are assigned according to data sources and assumptions.

The flow property of most elementary flows is mass and, therefore, the values of the $\mathrm{CF}_{\mathrm{RMI}}$ are calculated in the unit $\mathrm{kg} / \mathrm{kg}$. The flow property of the elementary flows "Gas, mine, off-gas, process, coal mining" and "Gas, natural, in ground" is volume and, therefore, the values of the $\mathrm{CF}_{\mathrm{RMI}}$ are calculated in the unit $\mathrm{kg} / \mathrm{m}^{3}$.

The complete list of the 143 elementary flows "resource, in ground" of the ecoinvent database and the assigned values for the $\mathrm{CF}_{\mathrm{RMI}}$ can be found in Table $\mathrm{A} 1$ and the values for the $\mathrm{CF}_{\mathrm{TMR}}$ in Table $\mathrm{A} 2$ in the Appendix A. An EcoSpold file in XML-Format to import the LCIA method PMF into the software openLCA (version 1.7) for use with the ecoinvent database (version 3.1, cut-off LCI) is provided in the Supplementary Materials. 


\section{Discussion}

Resource efficiency is high on the political agenda and there is a wide consensus that economic performance should be decoupled from natural resource use. At present, the measurement of the life cycle wide use of raw materials on a product level is still in its initial stage, mainly due to the absence of defined standards, reliable data, and adequate software solutions. A new LCIA method including the global median data for the CF has been developed to measure the material intensity of products and services. The PMF can easily be applied by LCA practitioners for automated calculation of the two material input indicators RMI and TMR, which has been shown using the open source software openLCA with the ecoinvent database. Since there is no internationally agreed standard on how to measure the PMF, both indicators should be used to provide two-fold information on the cumulative raw material use and on the total primary material requirement. While the latter can be regarded as a midpoint indicator of the environmental pressure at the locations of extraction, the former is a midpoint indicator for the environmental impact potential along the production chain up to a final disposal. Thus, both indicators convey complementary information. The PMF has been applied in recent case studies measuring the material intensity of chemical products, building structures, and electrical energy storage technologies [40-43].

Several LCIA methods and indicators focusing on resource use and depletion have been developed in recent years [44]. The most prominent is the Abiotic Depletion Potential (ADP). The indicator has been proposed to assess the relative scarcity of abiotic resources [45]. The characterization model has been controversially discussed and the underlying data for calculating the impact indicator covering 42 materials have not been updated since 2009 [46]. Since the ADP assesses resource depletion related to the natural resource availability, it is not an impact indicator related to the natural environment [47]. The PMF is following a different approach by quantifying the used and processed material as well as the total extraction of primary material from nature. With the extraction process, the support and service functions of the moved and used material are disturbed or lost, e.g., sand dredging in coastal areas leading to land erosion, ecosystem damages, and increased risk of flooding [48]. Neither RMI nor TMR can measure substance-specific environmental impacts such as eco-toxicity. For these impacts, other indicators must be used. Raw material extraction is an input-oriented intervention according to the LCA framework and, therefore, a good basis for measuring resource efficiency [49]. As the PMF is calculated per FU, the inverse is a measure for the life cycle wide material efficiency.

\section{Outlook}

As a first step, the global median values for $42 \mathrm{CF}_{\mathrm{RMI}}$ and for $36 \mathrm{CF}_{\mathrm{TMR}}$ out of 78 abiotic materials in the ecoinvent database are provided. Nevertheless, there is still a considerable need for further research to improve the data basis and to overcome limitations of the approach. (1) The data for calculation of the $\mathrm{CF}$ for the remaining abiotic materials have to be collected and a database for a regular update has to be set up. (2) The uncertainties in the CF have to be quantified. For the first estimation, the value of the $\mathrm{CF}_{\mathrm{RMI}}$ copper calculated from the RMG database- $143 \mathrm{~kg}$ raw material per $\mathrm{kg}$ copper-has been compared with the results from the IFEU report and the ecoinvent database. The ecoinvent elementary flow, which is related to the global median copper production, gives a concentration of $0.36 \%$ copper in crude ore. This would result in $278 \mathrm{~kg}$ raw material per kg copper. Whereas the primary data source shows a concentration of $0.99 \%$ copper in crude ore [32] resulting in $101 \mathrm{~kg}$ raw material per $\mathrm{kg}$ copper. This result is close to $99.5 \mathrm{~kg}$ raw material per kg copper calculated from the IFEU report [34]. (3) At present, the calculation of the $\mathrm{CF}_{\mathrm{RMI}}$ is based only on the content of the material in the raw material. In the future, the losses during further processing and, thus, the overall process efficiency of mining, beneficiation, and smelting, which is, e.g., for the global copper production around 80\% [32], should be considered. (4) The provided values for the CF are global median values that take international markets and supply chains for raw materials into account. The calculation of the $\mathrm{CF}_{\mathrm{RMI}}$ using the RMG database has shown that the local conditions of the raw material extraction, in the case of metals and the ore grade of the specific mine, has a significant impact on the results. Therefore, it is advisable to 
adjust the values in the impact category, if the exact origin and concentration of the material in the raw material is known. In the future, the calculation method of PMF for $\mathrm{RMI}_{\text {biotic }}$ and $\mathrm{TMR}_{\text {biotic }}$ and the values for $\mathrm{CF}_{\mathrm{RMI}}$ and $\mathrm{CF}_{\mathrm{TMR}}$ of biotic materials will be provided.

Supplementary Materials: The following are available online at http://www.mdpi.com/2079-9276/8/2/61/s1, LCIA method PMF as EcoSpold file in XML-Format for openLCA (version 1.7) and ecoinvent database (version 3.1, cut-off LCI) (see page 9).

Author Contributions: C.M. prepared the article including research, assessment, and writing. S.B. provided support across all phases and edited the article.

Funding: This research received no external funding.

Conflicts of Interest: The authors declare no conflict of interest.

\section{Abbreviations}

\begin{tabular}{|c|c|}
\hline Nomenclature & \\
\hline c & concentration \\
\hline coeff $_{\text {extraction }}$ & extraction coefficient \\
\hline $\mathrm{m}$ & mass \\
\hline ADP & Abiotic Depletion Potential \\
\hline $\mathrm{AF}$ & Allocation Factor \\
\hline $\mathrm{AP}$ & Average Market Price \\
\hline CF & Characterization Factor \\
\hline $\mathrm{CF}_{\mathrm{RMI}}$ & Characterization Factor Raw Material Input \\
\hline $\mathrm{CF}_{\mathrm{TMR}}$ & Characterization Factor Total Material Requirement \\
\hline CED & Cumulative Energy Demand \\
\hline CRD & Cumulated Raw Material Demand \\
\hline DMI & Direct Material Input \\
\hline FU & Functional Unit \\
\hline GWI & Global Warming Impact \\
\hline GWP & Global Warming Potential \\
\hline PMF & Product Material Footprint \\
\hline RMC & Raw Material Consumption \\
\hline RME & Raw Material Equivalents \\
\hline RMI & Raw Material Input \\
\hline $\mathrm{RMI}_{\text {abiotic }}$ & Abiotic Raw Material Input \\
\hline $\mathrm{RMI}_{\text {biotic }}$ & Biotic Raw Material Input \\
\hline TMR & Total Material Requirement \\
\hline $\mathrm{TMR}_{\text {abiotic }}$ & Abiotic Total Material Requirement \\
\hline $\mathrm{TMR}_{\text {biotic }}$ & Biotic Total Material Requirement \\
\hline Acronyms & \\
\hline AoP & Area of Protection \\
\hline EU & European Union \\
\hline IFEU & Institut für Energie- und Umweltforschung, Heidelberg \\
\hline LCA & Life Cycle Assessment \\
\hline LCI & Life Cycle Inventory \\
\hline LCIA & Life Cycle Impact Assessment \\
\hline MIPS & Material Input Per Service Unit \\
\hline $\mathrm{MMO}$ & Multiple Metal Ore \\
\hline RMG & Raw Materials Group \\
\hline SDGs & Sustainable Development Goals \\
\hline $\mathrm{SMO}$ & Single Metal Ore \\
\hline SOS & Safe Operating Space \\
\hline USGS & United States Geological Survey \\
\hline XML & Extended Markup Language \\
\hline
\end{tabular}




\section{Appendix A}

Table A1. Values for Characterization Factor Raw Material Input CF RMI assigned to the elementary flows "resource, in ground" of the ecoinvent database (version 3.1, cut-off LCI).

\begin{tabular}{|c|c|c|}
\hline No. & Elementary Flow "Resource, in Ground" & $\mathrm{CF}_{\mathrm{RMI}}[\mathrm{kg} / \mathrm{kg}]$ \\
\hline 1 & Aluminum, $24 \%$ in bauxite, $11 \%$ in crude ore, in ground & 5.3 \\
\hline 2 & Aluminum, in ground & 5.3 \\
\hline 3 & Anhydrite, in ground & 1.0 \\
\hline 4 & Barite, $15 \%$ in crude ore, in ground & 6.7 \\
\hline 5 & Basalt, in ground & 1.0 \\
\hline 6 & Borax, in ground & 1.0 \\
\hline 7 & Cadmium, $0.30 \%$ in sulfide, $\mathrm{Cd} 0.18 \%, \mathrm{~Pb}, \mathrm{Zn}, \mathrm{Ag}$, $\mathrm{In}$, in ground & 735.0 \\
\hline 8 & Calcium carbonate, in ground & 1.0 \\
\hline 9 & Carbon, in organic matter, in soil & 1.0 \\
\hline 10 & Cerium, $24 \%$ in bastnasite, $2.4 \%$ in crude ore, in ground & 42.0 \\
\hline 11 & Chromium, $25.5 \%$ in chromite, $11.6 \%$ in crude ore, in ground & 2.7 \\
\hline 12 & Chrysotile, in ground & 1.0 \\
\hline 13 & Cinnabar, in ground & 1.0 \\
\hline 14 & Clay, bentonite, in ground & 1.0 \\
\hline 15 & Clay, unspecified, in ground & 1.0 \\
\hline 16 & Coal, brown, in ground & 1.0 \\
\hline 17 & Coal, hard, unspecified, in ground & 1.0 \\
\hline 18 & Cobalt, in ground & 115.0 \\
\hline 19 & Colemanite, in ground & 1.0 \\
\hline 20 & Copper, $0.52 \%$ in sulfide, $\mathrm{Cu} 0.27 \%$ and $\mathrm{Mo} 8.2 \mathrm{E}-3 \%$ in crude ore, in ground & 143.0 \\
\hline 21 & Copper, $0.59 \%$ in sulfide, $\mathrm{Cu} 0.22 \%$ and Mo $8.2 \mathrm{E}-3 \%$ in crude ore, in ground & 143.0 \\
\hline 22 & Copper, $0.97 \%$ in sulfide, $\mathrm{Cu} 0.36 \%$ and Mo $4.1 \mathrm{E}-2 \%$ in crude ore, in ground & 143.0 \\
\hline 23 & Copper, $0.99 \%$ in sulfide, $\mathrm{Cu} 0.36 \%$ and $\mathrm{Mo} 8.2 \mathrm{E}-3 \%$ in crude ore, in ground & 143.0 \\
\hline 24 & Copper, $1.13 \%$ in sulfide, $\mathrm{Cu} 0.76 \%$ and $\mathrm{Ni} 0.76 \%$ in crude ore, in ground & 143.0 \\
\hline 25 & Copper, $1.18 \%$ in sulfide, $\mathrm{Cu} 0.39 \%$ and Mo $8.2 \mathrm{E}-3 \%$ in crude ore, in ground & 143.0 \\
\hline 26 & Copper, $1.42 \%$ in sulfide, $\mathrm{Cu} 0.81 \%$ and $\mathrm{Mo} 8.2 \mathrm{E}-3 \%$ in crude ore, in ground & 143.0 \\
\hline 27 & Copper, $2.19 \%$ in sulfide, Cu $1.83 \%$ and Mo $8.2 \mathrm{E}-3 \%$ in crude ore, in ground & 143.0 \\
\hline 28 & Copper, $\mathrm{Cu} 0.2 \%$, in mixed ore, in ground & 143.0 \\
\hline 29 & Copper, $\mathrm{Cu} 0.38 \%$, Au 9.7E- $4 \%$, Ag 9.7E- $4 \%$, $\mathrm{Zn} 0.63 \%, \mathrm{~Pb} 0.014 \%$, in ore, in ground & 143.0 \\
\hline 30 & $\mathrm{Cu}, \mathrm{Cu} 3.2 \mathrm{E}+0 \%$, Pt $2.5 \mathrm{E}-4 \%$, Pd $7.3 \mathrm{E}-4 \%$, Rh $2.0 \mathrm{E}-5 \%, \mathrm{Ni} 2.3 \mathrm{E}+0 \%$ in ore, in ground & 143.0 \\
\hline 31 & $\mathrm{Cu}, \mathrm{Cu} 5.2 \mathrm{E}-2 \%, \mathrm{Pt} 4.8 \mathrm{E}-4 \%$, Pd $2.0 \mathrm{E}-4 \%$, Rh $2.4 \mathrm{E}-5 \%$, Ni $3.7 \mathrm{E}-2 \%$ in ore, in ground & 143.0 \\
\hline 32 & Diatomite, in ground & 1.0 \\
\hline 33 & Dolomite, in ground & 1.0 \\
\hline 34 & Energy, geothermal, converted & 0.0 \\
\hline 35 & Europium, $0.06 \%$ in bastnasite, $0.006 \%$ in crude ore, in ground & $16,667.0$ \\
\hline 36 & Feldspar, in ground & 1.0 \\
\hline 37 & Fluorine, $4.5 \%$ in apatite, $1 \%$ in crude ore, in ground & 67.0 \\
\hline 38 & Fluorine, $4.5 \%$ in apatite, $3 \%$ in crude ore, in ground & 67.0 \\
\hline 39 & Fluorspar, $92 \%$, in ground & 1.1 \\
\hline 40 & Gadolinium, $0.15 \%$ in bastnasite, $0.015 \%$ in crude ore, in ground & 6667.0 \\
\hline 41 & Gallium, $0.014 \%$ in bauxite, in ground & 7143.0 \\
\hline 42 & Gallium, in ground & 7143.0 \\
\hline 43 & Gangue, bauxite, in ground & 1.0 \\
\hline 44 & Gas, mine, off-gas, process, coal mining * & 0.8 \\
\hline 45 & Gas, natural, in ground * & 0.8 \\
\hline 46 & Gold, Au 1.1E-4\%, Ag 4.2E-3\%, in ore, in ground & $943,610.0$ \\
\hline 47 & Gold, Au $1.3 \mathrm{E}-4 \%$, Ag $4.6 \mathrm{E}-5 \%$, in ore, in ground & $943,610.0$ \\
\hline 48 & Gold, Au $1.4 \mathrm{E}-4 \%$, in ore, in ground & $943,610.0$ \\
\hline 49 & Gold, Au $1.8 \mathrm{E}-4 \%$, in mixed ore, in ground & $943,610.0$ \\
\hline 50 & Gold, Au $2.1 \mathrm{E}-4 \%$, Ag $2.1 \mathrm{E}-4 \%$, in ore, in ground & $943,610.0$ \\
\hline 51 & Gold, Au 4.3E-4\%, in ore, in ground & $943,610.0$ \\
\hline 52 & Gold, Au 4.9E-5\%, in ore, in ground & $943,610.0$ \\
\hline 53 & Gold, Au 5.4E-4\%, Ag 1.5E-5\%, in ore, in ground & $943,610.0$ \\
\hline 54 & Gold, Au $6.7 \mathrm{E}-4 \%$, in ore, in ground & $943,610.0$ \\
\hline 55 & Gold, $\mathrm{Au} 6.8 \mathrm{E}-4 \%$, Ag $1.5 \mathrm{E}-4 \%$, in ore, in ground & $943,610.0$ \\
\hline 56 & Gold, Au $7.1 \mathrm{E}-4 \%$, in ore, in ground & $943,610.0$ \\
\hline
\end{tabular}


Table A1. Cont.

\begin{tabular}{|c|c|c|}
\hline No. & Elementary Flow "Resource, in Ground" & $\mathrm{CF}_{\mathrm{RMI}}[\mathrm{kg} / \mathrm{kg}]$ \\
\hline 57 & Gold, Au 9.7E-4\%, Ag 9.7E-4\%, Zn 0.63\%, Cu 0.38\%, $\mathrm{Pb} 0.014 \%$, in ore, in ground & $943,610.0$ \\
\hline 58 & Gold, Au 9.7E-5\%, Ag 7.6E-5\%, in ore, in ground & $943,610.0$ \\
\hline 59 & Granite, in ground & 1.0 \\
\hline 60 & Gravel, in ground & 1.0 \\
\hline 61 & Gypsum, in ground & 1.0 \\
\hline 62 & Helium, $0.08 \%$ in natural gas, in ground & 1.0 \\
\hline 63 & Indium, $0.005 \%$ in sulfide, In $0.003 \%, \mathrm{~Pb}, \mathrm{Zn}, \mathrm{Ag}, \mathrm{Cd}$, in ground & 3334.0 \\
\hline 64 & Iron, $46 \%$ in ore, $25 \%$ in crude ore, in ground & 2.7 \\
\hline 65 & Iron, $72 \%$ in magnetite, $14 \%$ in crude ore, in ground & 2.7 \\
\hline 66 & Kaolinite, $24 \%$ in crude ore, in ground & 4.2 \\
\hline 67 & Kieserite, $25 \%$ in crude ore, in ground & 4.0 \\
\hline 68 & Lanthanum, $7.2 \%$ in bastnasite, $0.72 \%$ in crude ore, in ground & 139.0 \\
\hline 69 & Lead, $5.0 \%$ in sulfide, $\mathrm{Pb} 3.0 \%, \mathrm{Zn}, \mathrm{Ag}, \mathrm{Cd}$, In, in ground & 12.0 \\
\hline 70 & Lead, $\mathrm{Pb} 0.014 \%$, Au 9.7E-4\%, Ag 9.7E-4\%, Zn $0.63 \%, \mathrm{Cu} 0.38 \%$, in ore, in ground & 12.0 \\
\hline 71 & Lead, $\mathrm{Pb} 3.6 \mathrm{E}-1 \%$, in mixed ore, in ground & 12.0 \\
\hline 72 & Lithium, $0.15 \%$ in brine, in ground & 667.0 \\
\hline 73 & Magnesite, $60 \%$ in crude ore, in ground & 1.7 \\
\hline 74 & Manganese, $35.7 \%$ in sedimentary deposit, $14.2 \%$ in crude ore, in ground & 2.8 \\
\hline 75 & Metamorphous rock, graphite containing, in ground & 1.0 \\
\hline 76 & Molybdenum, $0.010 \%$ in sulfide, Mo $8.2 \mathrm{E}-3 \%$ and $\mathrm{Cu} 1.83 \%$ in crude ore, in ground & 981.0 \\
\hline 77 & Molybdenum, $0.014 \%$ in sulfide, $\mathrm{Mo} 8.2 \mathrm{E}-3 \%$ and $\mathrm{Cu} 0.81 \%$ in crude ore, in ground & 981.0 \\
\hline 78 & Molybdenum, $0.016 \%$ in sulfide, $\mathrm{Mo} 8.2 \mathrm{E}-3 \%$ and $\mathrm{Cu} 0.27 \%$ in crude ore, in ground & 981.0 \\
\hline 79 & Molybdenum, $0.022 \%$ in sulfide, $\mathrm{Mo} 8.2 \mathrm{E}-3 \%$ and $\mathrm{Cu} 0.22 \%$ in crude ore, in ground & 981.0 \\
\hline 80 & Molybdenum, $0.022 \%$ in sulfide, Mo $8.2 \mathrm{E}-3 \%$ and $\mathrm{Cu} 0.36 \%$ in crude ore, in ground & 981.0 \\
\hline 81 & Molybdenum, $0.025 \%$ in sulfide, $\mathrm{Mo} 8.2 \mathrm{E}-3 \%$ and $\mathrm{Cu} 0.39 \%$ in crude ore, in ground & 981.0 \\
\hline 82 & Molybdenum, $0.11 \%$ in sulfide, $\mathrm{Mo} 4.1 \mathrm{E}-2 \%$ and $\mathrm{Cu} 0.36 \%$ in crude ore, in ground & 981.0 \\
\hline 83 & Neodymium, $4 \%$ in bastnasite, $0.4 \%$ in crude ore, in ground & 250.0 \\
\hline 84 & $\mathrm{Ni}, \mathrm{Ni} 2.3 \mathrm{E}+0 \%$, Pt $2.5 \mathrm{E}-4 \%$, Pd $7.3 \mathrm{E}-4 \%$, Rh $2.0 \mathrm{E}-5 \%, \mathrm{Cu} 3.2 \mathrm{E}+0 \%$ in ore, in ground & 63.0 \\
\hline 85 & $\mathrm{Ni}, \mathrm{Ni} 3.7 \mathrm{E}-2 \%$, Pt $4.8 \mathrm{E}-4 \%$, Pd $2.0 \mathrm{E}-4 \%$, Rh $2.4 \mathrm{E}-5 \%$, Cu $5.2 \mathrm{E}-2 \%$ in ore, in ground & 63.0 \\
\hline 86 & Nickel, $1.13 \%$ in sulfide, $\mathrm{Ni} 0.76 \%$ and $\mathrm{Cu} 0.76 \%$ in crude ore, in ground & 63.0 \\
\hline 87 & Nickel, $1.98 \%$ in silicates, $1.04 \%$ in crude ore, in ground & 63.3 \\
\hline 88 & Oil, crude, in ground & 1.0 \\
\hline 89 & Olivine, in ground & 1.0 \\
\hline 90 & $\mathrm{Pd}, \mathrm{Pd} 2.0 \mathrm{E}-4 \%$, Pt $4.8 \mathrm{E}-4 \%$, Rh $2.4 \mathrm{E}-5 \%$, Ni $3.7 \mathrm{E}-2 \%, \mathrm{Cu} 5.2 \mathrm{E}-2 \%$ in ore, in ground & $66,063.0$ \\
\hline 91 & $\mathrm{Pd}, \mathrm{Pd} 7.3 \mathrm{E}-4 \%$, Pt $2.5 \mathrm{E}-4 \%$, Rh $2.0 \mathrm{E}-5 \%, \mathrm{Ni} 2.3 \mathrm{E}+0 \%, \mathrm{Cu} 3.2 \mathrm{E}+0 \%$ in ore, in ground & $66,063.0$ \\
\hline 92 & Perlite, in ground & 1.0 \\
\hline 93 & Phosphorus, $18 \%$ in apatite, $12 \%$ in crude ore, in ground & 17.0 \\
\hline 94 & Phosphorus, $18 \%$ in apatite, $4 \%$ in crude ore, in ground & 17.0 \\
\hline 95 & Praseodymium, $0.42 \%$ in bastnasite, $0.042 \%$ in crude ore, in ground & 2381.0 \\
\hline 96 & Pt, Pt $2.5 \mathrm{E}-4 \%$, Pd $7.3 \mathrm{E}-4 \%$, Rh $2.0 \mathrm{E}-5 \%$, Ni $2.3 \mathrm{E}+0 \%, \mathrm{Cu} 3.2 \mathrm{E}+0 \%$ in ore, in ground & $274,186.0$ \\
\hline 97 & $\mathrm{Pt}, \mathrm{Pt} 4.8 \mathrm{E}-4 \%$, Pd $2.0 \mathrm{E}-4 \%$, Rh $2.4 \mathrm{E}-5 \%$, Ni $3.7 \mathrm{E}-2 \%, \mathrm{Cu} 5.2 \mathrm{E}-2 \%$ in ore, in ground & $274,186.0$ \\
\hline 98 & Pumice, in ground & 1.0 \\
\hline 99 & Pyrite, in ground & 1.0 \\
\hline 100 & Pyrolusite, in ground & 1.0 \\
\hline 101 & Rh, Rh $2.0 \mathrm{E}-5 \%$, Pt $2.5 \mathrm{E}-4 \%$, Pd $7.3 \mathrm{E}-4 \%$, Ni $2.3 \mathrm{E}+0 \%, \mathrm{Cu} 3.2 \mathrm{E}+0 \%$ in ore, in ground & $520,571.0$ \\
\hline 102 & Rh, Rh $2.4 \mathrm{E}-5 \%$, Pt $4.8 \mathrm{E}-4 \%$, Pd $2.0 \mathrm{E}-4 \%$, Ni $3.7 \mathrm{E}-2 \%, \mathrm{Cu} 5.2 \mathrm{E}-2 \%$ in ore, in ground & $520,571.0$ \\
\hline 103 & Rhenium, in crude ore, in ground & 1.0 \\
\hline 104 & Samarium, $0.3 \%$ in bastnasite, $0.03 \%$ in crude ore, in ground & 3333.0 \\
\hline 105 & Sand, unspecified, in ground & 1.0 \\
\hline 106 & Shale, in ground & 1.0 \\
\hline 107 & Silver, $0.007 \%$ in sulfide, $\mathrm{Ag} 0.004 \%, \mathrm{~Pb}, \mathrm{Zn}, \mathrm{Cd}, \mathrm{In}$, in ground & $10,561.0$ \\
\hline 108 & Silver, $0.01 \%$ in crude ore, in ground & $10,561.0$ \\
\hline 109 & Silver, $3.2 \mathrm{ppm}$ in sulfide, $\mathrm{Ag} 1.2 \mathrm{ppm}, \mathrm{Cu}$ and $\mathrm{Te}$, in crude ore, in ground & $10,561.0$ \\
\hline 110 & Silver, $\mathrm{Ag} 1.5 \mathrm{E}-4 \%$, Au $6.8 \mathrm{E}-4 \%$, in ore, in ground & $10,561.0$ \\
\hline 111 & Silver, Ag $1.5 \mathrm{E}-5 \%$, Au $5.4 \mathrm{E}-4 \%$, in ore, in ground & $10,561.0$ \\
\hline 112 & Silver, Ag 2.1E-4\%, Au 2.1E-4\%, in ore, in ground & $10,561.0$ \\
\hline 113 & Silver, Ag $4.2 \mathrm{E}-3 \%$, Au $1.1 \mathrm{E}-4 \%$, in ore, in ground & $10,561.0$ \\
\hline 114 & Silver, Ag $4.6 \mathrm{E}-5 \%$, Au $1.3 \mathrm{E}-4 \%$, in ore, in ground & $10,561.0$ \\
\hline 115 & Silver, Ag $5.4 \mathrm{E}-3 \%$, in mixed ore, in ground & $10,561.0$ \\
\hline 116 & Silver, Ag 7.6E-5\%, Au 9.7E- $5 \%$, in ore, in ground & $10,561.0$ \\
\hline
\end{tabular}


Table A1. Cont.

\begin{tabular}{|c|c|c|}
\hline No. & Elementary Flow "Resource, in Ground” & $\mathrm{CF}_{\mathrm{RMI}}[\mathrm{kg} / \mathrm{kg}]$ \\
\hline 117 & Silver, Ag 9.7E-4\%, Au 9.7E- $4 \%$, Zn $0.63 \%, \mathrm{Cu} 0.38 \%, \mathrm{~Pb} 0.014 \%$, in ore, in ground & $10,561.0$ \\
\hline 118 & Sodium chloride, in ground & 1.0 \\
\hline 119 & Sodium nitrate, in ground & 1.0 \\
\hline 120 & Sodium sulphate, various forms, in ground & 1.0 \\
\hline 121 & Spodumene, in ground & 1.0 \\
\hline 122 & Steatite, in ground & 1.0 \\
\hline 123 & Stibnite, in ground & 1.0 \\
\hline 124 & Sulfur, in ground & 1.0 \\
\hline 125 & Sylvite, $25 \%$ in sylvinite, in ground & 4.0 \\
\hline 126 & Talc, in ground & 1.0 \\
\hline 127 & Tantalum, $81.9 \%$ in tantalite, $1.6 \mathrm{E}-4 \%$ in crude ore, in ground & 6105.0 \\
\hline 128 & Tellurium, $0.5 \mathrm{ppm}$ in sulfide, $\mathrm{Te} 0.2 \mathrm{ppm}, \mathrm{Cu}$ and $\mathrm{Ag}$, in crude ore, in ground & $5,000,000.0$ \\
\hline 129 & Tin, $79 \%$ in cassiterite, $0.1 \%$ in crude ore, in ground & 415.0 \\
\hline 130 & $\mathrm{TiO}_{2}, 54 \%$ in ilmenite, $18 \%$ in crude ore, in ground & 98.0 \\
\hline 131 & $\mathrm{TiO}_{2}, 54 \%$ in ilmenite, $2.6 \%$ in crude ore, in ground & 98.0 \\
\hline 132 & $\mathrm{TiO}_{2}, 95 \%$ in rutile, $0.40 \%$ in crude ore, in ground & 98.0 \\
\hline 133 & Ulexite, in ground & 1.0 \\
\hline 134 & Uranium, in ground & 1000.0 \\
\hline 135 & Vermiculite, in ground & 1.0 \\
\hline 136 & Volume occupied, final repository for low-active radioactive waste & 0.0 \\
\hline 137 & Volume occupied, final repository for radioactive waste & 0.0 \\
\hline 138 & Volume occupied, underground deposit & 0.0 \\
\hline 139 & Zinc, $9.0 \%$ in sulfide, $\mathrm{Zn} 5.3 \%, \mathrm{~Pb}, \mathrm{Ag}, \mathrm{Cd}, \mathrm{In}$, in ground & 13.0 \\
\hline 140 & Zinc, $\mathrm{Zn} 0.63 \%$, Au 9.7E-4\%, Ag 9.7E-4\%, Cu 0.38\%, Pb 0.014\%, in ore, in ground & 13.0 \\
\hline 141 & Zinc, $\mathrm{Zn} 3.1 \%$, in mixed ore, in ground & 13.0 \\
\hline 142 & Zirconia, as baddeleyite, in ground & 1.0 \\
\hline 143 & Zirconium, $50 \%$ in zircon, $0.39 \%$ in crude ore, in ground & 53.0 \\
\hline
\end{tabular}

${ }^{*}$ in $[\mathrm{kg} / \mathrm{MJ}]$.

Table A2. Values for the Characterization Factors Total Material Requirement CF TMR assigned to the elementary flows "resource, in ground" of ecoinvent database (version 3.1, cut-off LCI).

\begin{tabular}{clr}
\hline No. & \multicolumn{1}{c}{ Elementary Flow “Resource, in Ground” } & CF $_{\text {TMR }}$ [kg/kg] \\
\hline 1 & Aluminum, 24\% in bauxite, 11\% in crude ore, in ground & 11.0 \\
2 & Aluminum, in ground & 11.0 \\
3 & Anhydrite, in ground & 1.1 \\
4 & Barite, 15\% in crude ore, in ground & 11.0 \\
5 & Basalt, in ground & 1.01 \\
6 & Borax, in ground & 1.1 \\
7 & Cadmium, 0.30\% in sulfide, Cd 0.18\%, Pb, Zn, Ag, In, in ground & 735.0 \\
8 & Calcium carbonate, in ground & 1.0 \\
9 & Carbon, in organic matter, in soil & 1.0 \\
10 & Cerium, 24\% in bastnasite, 2.4\% in crude ore, in ground & 42.0 \\
11 & Chromium, 25.5\% in chromite, 11.6\% in crude ore, in ground & 5.9 \\
12 & Chrysotile, in ground & 1.0 \\
13 & Cinnabar, in ground & 1.0 \\
14 & Clay, bentonite, in ground & 2.3 \\
15 & Clay, unspecified, in ground & 2.3 \\
16 & Coal, brown, in ground & 1.3 \\
17 & Coal, hard, unspecified, in ground & 1.2 \\
18 & Cobalt, in ground & 115.0 \\
19 & Colemanite, in ground & 1.0 \\
20 & Copper, 0.52\% in sulfide, Cu 0.27\% and Mo 8.2E-3\% in crude ore, in ground & 157.0 \\
21 & Copper, 0.59\% in sulfide, Cu 0.22\% and Mo 8.2E-3\% in crude ore, in ground & 157.0 \\
22 & Copper, 0.97\% in sulfide, Cu 0.36\% and Mo 4.1E-2\% in crude ore, in ground & 157.0 \\
23 & Copper, 0.99\% in sulfide, Cu 0.36\% and Mo 8.2E-3\% in crude ore, in ground & 157.0 \\
24 & Copper, 1.13\% in sulfide, Cu 0.76\% and Ni 0.76\% in crude ore, in ground & 157.0 \\
25 & Copper, 1.18\% in sulfide, Cu 0.39\% and Mo 8.2E-3\% in crude ore, in ground & 157.0 \\
\hline
\end{tabular}


Table A2. Cont.

\begin{tabular}{|c|c|c|}
\hline No. & Elementary Flow "Resource, in Ground" & $\mathrm{CF}_{\mathrm{TMR}}[\mathrm{kg} / \mathrm{kg}]$ \\
\hline 26 & Copper, $1.42 \%$ in sulfide, $\mathrm{Cu} 0.81 \%$ and $\mathrm{Mo} 8.2 \mathrm{E}-3 \%$ in crude ore, in ground & 157.0 \\
\hline 27 & Copper, $2.19 \%$ in sulfide, $\mathrm{Cu} 1.83 \%$ and Mo $8.2 \mathrm{E}-3 \%$ in crude ore, in ground & 157.0 \\
\hline 28 & Copper, $\mathrm{Cu} 0.2 \%$, in mixed ore, in ground & 157.0 \\
\hline 29 & Copper, $\mathrm{Cu} 0.38 \%$, Au 9.7E-4\%, Ag 9.7E- $4 \%$, $\mathrm{Zn} 0.63 \%, \mathrm{~Pb} 0.014 \%$, in ore, in ground & 157.0 \\
\hline 30 & $\mathrm{Cu}, \mathrm{Cu} 3.2 \mathrm{E}+0 \%, \mathrm{Pt} 2.5 \mathrm{E}-4 \%, \mathrm{Pd} 7.3 \mathrm{E}-4 \%, \mathrm{Rh} 2.0 \mathrm{E}-5 \%, \mathrm{Ni} 2.3 \mathrm{E}+0 \%$ in ore, in ground & 157.0 \\
\hline 31 & $\mathrm{Cu}, \mathrm{Cu} 5.2 \mathrm{E}-2 \%$, Pt $4.8 \mathrm{E}-4 \%$, Pd $2.0 \mathrm{E}-4 \%$, Rh $2.4 \mathrm{E}-5 \%$, Ni $3.7 \mathrm{E}-2 \%$ in ore, in ground & 157.0 \\
\hline 32 & Diatomite, in ground & 1.1 \\
\hline 33 & Dolomite, in ground & 1.01 \\
\hline 34 & Energy, geothermal, converted & 0.0 \\
\hline 35 & Europium, $0.06 \%$ in bastnasite, $0.006 \%$ in crude ore, in ground & $16,667.0$ \\
\hline 36 & Feldspar, in ground & 1.1 \\
\hline 37 & Fluorine, $4.5 \%$ in apatite, $1 \%$ in crude ore, in ground & 67.0 \\
\hline 38 & Fluorine, $4.5 \%$ in apatite, $3 \%$ in crude ore, in ground & 67.0 \\
\hline 39 & Fluorspar, $92 \%$, in ground & 1.4 \\
\hline 40 & Gadolinium, $0.15 \%$ in bastnasite, $0.015 \%$ in crude ore, in ground & 6667.0 \\
\hline 41 & Gallium, $0.014 \%$ in bauxite, in ground & 7143.0 \\
\hline 42 & Gallium, in ground & 7143.0 \\
\hline 43 & Gangue, bauxite, in ground & 1.0 \\
\hline 44 & Gas, mine, off-gas, process, coal mining * & 0.8 \\
\hline 45 & Gas, natural, in ground * & 0.8 \\
\hline 46 & Gold, Au 1.1E-4\%, Ag 4.2E-3\%, in ore, in ground & $2,906,319.0$ \\
\hline 47 & Gold, Au $1.3 \mathrm{E}-4 \%$, Ag $4.6 \mathrm{E}-5 \%$, in ore, in ground & $2,906,319.0$ \\
\hline 48 & Gold, Au $1.4 \mathrm{E}-4 \%$, in ore, in ground & $2,906,319.0$ \\
\hline 49 & Gold, Au $1.8 \mathrm{E}-4 \%$, in mixed ore, in ground & $2,906,319.0$ \\
\hline 50 & Gold, Au $2.1 \mathrm{E}-4 \%$, Ag $2.1 \mathrm{E}-4 \%$, in ore, in ground & $2,906,319.0$ \\
\hline 51 & Gold, Au $4.3 \mathrm{E}-4 \%$, in ore, in ground & $2,906,319.0$ \\
\hline 52 & Gold, Au $4.9 \mathrm{E}-5 \%$, in ore, in ground & $2,906,319.0$ \\
\hline 53 & Gold, Au 5.4E-4\%, Ag 1.5E-5\%, in ore, in ground & $2,906,319.0$ \\
\hline 54 & Gold, Au $6.7 \mathrm{E}-4 \%$, in ore, in ground & $2,906,319.0$ \\
\hline 55 & Gold, Au $6.8 \mathrm{E}-4 \%, \mathrm{Ag} 1.5 \mathrm{E}-4 \%$, in ore, in ground & $2,906,319.0$ \\
\hline 56 & Gold, Au $7.1 \mathrm{E}-4 \%$, in ore, in ground & $2,906,319.0$ \\
\hline 57 & Gold, Au 9.7E-4\%, Ag 9.7E-4\%, Zn 0.63\%, Cu 0.38\%, $\mathrm{Pb} 0.014 \%$, in ore, in ground & $2,906,319.0$ \\
\hline 58 & Gold, Au 9.7E-5\%, Ag 7.6E-5\%, in ore, in ground & $2,906,319.0$ \\
\hline 59 & Granite, in ground & 1.01 \\
\hline 60 & Gravel, in ground & 1.01 \\
\hline 61 & Gypsum, in ground & 1.04 \\
\hline 62 & Helium, $0.08 \%$ in natural gas, in ground & 1.0 \\
\hline 63 & Indium, $0.005 \%$ in sulfide, In $0.003 \%, \mathrm{~Pb}, \mathrm{Zn}, \mathrm{Ag}, \mathrm{Cd}$, in ground & 3334.0 \\
\hline 64 & Iron, $46 \%$ in ore, $25 \%$ in crude ore, in ground & 5.1 \\
\hline 65 & Iron, $72 \%$ in magnetite, $14 \%$ in crude ore, in ground & 5.1 \\
\hline 66 & Kaolinite, $24 \%$ in crude ore, in ground & 6.3 \\
\hline 67 & Kieserite, $25 \%$ in crude ore, in ground & 4.0 \\
\hline 68 & Lanthanum, $7.2 \%$ in bastnasite, $0.72 \%$ in crude ore, in ground & 139.0 \\
\hline 69 & Lead, $5.0 \%$ in sulfide, $\mathrm{Pb} 3.0 \%, \mathrm{Zn}, \mathrm{Ag}, \mathrm{Cd}$, In, in ground & 15.0 \\
\hline 70 & Lead, $\mathrm{Pb} 0.014 \%$, Au 9.7E-4\%, Ag 9.7E-4\%, Zn 0.63\%, Cu 0.38\%, in ore, in ground & 15.0 \\
\hline 71 & Lead, $\mathrm{Pb} 3.6 \mathrm{E}-1 \%$, in mixed ore, in ground & 15.0 \\
\hline 72 & Lithium, $0.15 \%$ in brine, in ground & 667.0 \\
\hline 73 & Magnesite, $60 \%$ in crude ore, in ground & 1.7 \\
\hline 74 & Manganese, $35.7 \%$ in sedimentary deposit, $14.2 \%$ in crude ore, in ground & 7.1 \\
\hline 75 & Metamorphous rock, graphite containing, in ground & 1.0 \\
\hline 76 & Molybdenum, $0.010 \%$ in sulfide, Mo $8.2 \mathrm{E}-3 \%$ and $\mathrm{Cu} 1.83 \%$ in crude ore, in ground & 1854.0 \\
\hline 77 & Molybdenum, $0.014 \%$ in sulfide, $\mathrm{Mo} 8.2 \mathrm{E}-3 \%$ and $\mathrm{Cu} 0.81 \%$ in crude ore, in ground & 1854.0 \\
\hline 78 & Molybdenum, $0.016 \%$ in sulfide, $\mathrm{Mo} 8.2 \mathrm{E}-3 \%$ and $\mathrm{Cu} 0.27 \%$ in crude ore, in ground & 1854.0 \\
\hline 79 & Molybdenum, $0.022 \%$ in sulfide, Mo $8.2 \mathrm{E}-3 \%$ and $\mathrm{Cu} 0.22 \%$ in crude ore, in ground & 1854.0 \\
\hline 80 & Molybdenum, $0.022 \%$ in sulfide, Mo $8.2 \mathrm{E}-3 \%$ and $\mathrm{Cu} 0.36 \%$ in crude ore, in ground & 1854.0 \\
\hline 81 & Molybdenum, $0.025 \%$ in sulfide, $\mathrm{Mo} 8.2 \mathrm{E}-3 \%$ and $\mathrm{Cu} 0.39 \%$ in crude ore, in ground & 1854.0 \\
\hline 82 & Molybdenum, $0.11 \%$ in sulfide, Mo $4.1 \mathrm{E}-2 \%$ and $\mathrm{Cu} 0.36 \%$ in crude ore, in ground & 1854.0 \\
\hline 83 & Neodymium, $4 \%$ in bastnasite, $0.4 \%$ in crude ore, in ground & 250.0 \\
\hline 84 & $\mathrm{Ni}, \mathrm{Ni} 2.3 \mathrm{E}+0 \%$, Pt $2.5 \mathrm{E}-4 \%$, Pd $7.3 \mathrm{E}-4 \%$, Rh $2.0 \mathrm{E}-5 \%, \mathrm{Cu} 3.2 \mathrm{E}+0 \%$ in ore, in ground & 101.0 \\
\hline 85 & $\mathrm{Ni}, \mathrm{Ni} 3.7 \mathrm{E}-2 \%$, Pt $4.8 \mathrm{E}-4 \%$, Pd $2.0 \mathrm{E}-4 \%$, Rh $2.4 \mathrm{E}-5 \%, \mathrm{Cu} 5.2 \mathrm{E}-2 \%$ in ore, in ground & 101.0 \\
\hline
\end{tabular}


Table A2. Cont.

\begin{tabular}{|c|c|c|}
\hline No. & Elementary Flow "Resource, in Ground" & $\mathrm{CF}_{\text {TMR }}[\mathrm{kg} / \mathrm{kg}]$ \\
\hline 86 & Nickel, $1.13 \%$ in sulfide, $\mathrm{Ni} 0.76 \%$ and $\mathrm{Cu} 0.76 \%$ in crude ore, in ground & 101.0 \\
\hline 87 & Nickel, $1.98 \%$ in silicates, $1.04 \%$ in crude ore, in ground & 101.0 \\
\hline 88 & Oil, crude, in ground & 1.2 \\
\hline 89 & Olivine, in ground & 1.0 \\
\hline 90 & $\mathrm{Pd}, \mathrm{Pd} 2.0 \mathrm{E}-4 \%$, Pt $4.8 \mathrm{E}-4 \%$, Rh $2.4 \mathrm{E}-5 \%$, Ni $3.7 \mathrm{E}-2 \%, \mathrm{Cu} 5.2 \mathrm{E}-2 \%$ in ore, in ground & $107,683.0$ \\
\hline 91 & $\mathrm{Pd}, \mathrm{Pd} 7.3 \mathrm{E}-4 \%$, Pt $2.5 \mathrm{E}-4 \%$, Rh $2.0 \mathrm{E}-5 \%, \mathrm{Ni} 2.3 \mathrm{E}+0 \%, \mathrm{Cu} 3.2 \mathrm{E}+0 \%$ in ore, in ground & $107,683.0$ \\
\hline 92 & Perlite, in ground & 1.0 \\
\hline 93 & Phosphorus, $18 \%$ in apatite, $12 \%$ in crude ore, in ground & 75.0 \\
\hline 94 & Phosphorus, $18 \%$ in apatite, $4 \%$ in crude ore, in ground & 75.0 \\
\hline 95 & Praseodymium, $0.42 \%$ in bastnasite, $0.042 \%$ in crude ore, in ground & 2381.0 \\
\hline 96 & Pt, Pt $2.5 \mathrm{E}-4 \%$, Pd $7.3 \mathrm{E}-4 \%$, Rh $2.0 \mathrm{E}-5 \%$, Ni $2.3 \mathrm{E}+0 \%, \mathrm{Cu} 3.2 \mathrm{E}+0 \%$ in ore, in ground & $445,826.0$ \\
\hline 97 & Pt, Pt $4.8 \mathrm{E}-4 \%$, Pd 2.0E-4\%, Rh $2.4 \mathrm{E}-5 \%$, Ni $3.7 \mathrm{E}-2 \%, \mathrm{Cu} 5.2 \mathrm{E}-2 \%$ in ore, in ground & $445,826.0$ \\
\hline 98 & Pumice, in ground & 1.0 \\
\hline 99 & Pyrite, in ground & 1.0 \\
\hline 100 & Pyrolusite, in ground & 1.0 \\
\hline 101 & $\mathrm{Rh}, \mathrm{Rh} 2.0 \mathrm{E}-5 \%$, Pt $2.5 \mathrm{E}-4 \%$, Pd $7.3 \mathrm{E}-4 \%$, Ni $2.3 \mathrm{E}+0 \%, \mathrm{Cu} 3.2 \mathrm{E}+0 \%$ in ore, in ground & $572,628.0$ \\
\hline 102 & Rh, Rh $2.4 \mathrm{E}-5 \%$, Pt $4.8 \mathrm{E}-4 \%$, Pd $2.0 \mathrm{E}-4 \%$, Ni $3.7 \mathrm{E}-2 \%$, Cu $5.2 \mathrm{E}-2 \%$ in ore, in ground & $572,628.0$ \\
\hline 103 & Rhenium, in crude ore, in ground & 1.0 \\
\hline 104 & Samarium, $0.3 \%$ in bastnasite, $0.03 \%$ in crude ore, in ground & 3333.0 \\
\hline 105 & Sand, unspecified, in ground & 1.0 \\
\hline 106 & Shale, in ground & 1.0 \\
\hline 107 & Silver, $0.007 \%$ in sulfide, $\mathrm{Ag} 0.004 \%, \mathrm{~Pb}, \mathrm{Zn}, \mathrm{Cd}$, In, in ground & $17,954.0$ \\
\hline 108 & Silver, $0.01 \%$ in crude ore, in ground & $17,954.0$ \\
\hline 109 & Silver, $3.2 \mathrm{ppm}$ in sulfide, $\mathrm{Ag} 1.2 \mathrm{ppm}, \mathrm{Cu}$ and $\mathrm{Te}$, in crude ore, in ground & $17,954.0$ \\
\hline 110 & Silver, Ag $1.5 \mathrm{E}-4 \%$, Au $6.8 \mathrm{E}-4 \%$, in ore, in ground & $17,954.0$ \\
\hline 111 & Silver, Ag $1.5 \mathrm{E}-5 \%$, Au $5.4 \mathrm{E}-4 \%$, in ore, in ground & $17,954.0$ \\
\hline 112 & Silver, $\mathrm{Ag} 2.1 \mathrm{E}-4 \%$, Au $2.1 \mathrm{E}-4 \%$, in ore, in ground & $17,954.0$ \\
\hline 113 & Silver, $\mathrm{Ag} 4.2 \mathrm{E}-3 \%$, Au $1.1 \mathrm{E}-4 \%$, in ore, in ground & $17,954.0$ \\
\hline 114 & Silver, $\mathrm{Ag} 4.6 \mathrm{E}-5 \%$, Au $1.3 \mathrm{E}-4 \%$, in ore, in ground & $17,954.0$ \\
\hline 115 & Silver, Ag $5.4 \mathrm{E}-3 \%$, in mixed ore, in ground & $17,954.0$ \\
\hline 116 & Silver, Ag 7.6E-5\%, Au 9.7E-5\%, in ore, in ground & $17,954.0$ \\
\hline 117 & Silver, Ag 9.7E- $4 \%$, Au 9.7E- $4 \%$, $\mathrm{Zn} 0.63 \%, \mathrm{Cu} 0.38 \%, \mathrm{~Pb} 0.014 \%$, in ore, in ground & $17,954.0$ \\
\hline 118 & Sodium chloride, in ground & 1.0 \\
\hline 119 & Sodium nitrate, in ground & 1.0 \\
\hline 120 & Sodium sulphate, various forms, in ground & 1.0 \\
\hline 121 & Spodumene, in ground & 1.0 \\
\hline 122 & Steatite, in ground & 2.0 \\
\hline 123 & Stibnite, in ground & 1.0 \\
\hline 124 & Sulfur, in ground & 1.0 \\
\hline 125 & Sylvite, $25 \%$ in sylvinite, in ground & 4.0 \\
\hline 126 & Talc, in ground & 1.1 \\
\hline 127 & Tantalum, $81.9 \%$ in tantalite, $1.6 \mathrm{E}-4 \%$ in crude ore, in ground & 6105.0 \\
\hline 128 & Tellurium, $0.5 \mathrm{ppm}$ in sulfide, $\mathrm{Te} 0.2 \mathrm{ppm}, \mathrm{Cu}$ and $\mathrm{Ag}$, in crude ore, in ground & $5,000,000.0$ \\
\hline 129 & Tin, $79 \%$ in cassiterite, $0.1 \%$ in crude ore, in ground & 502.0 \\
\hline 130 & $\mathrm{TiO}_{2}, 54 \%$ in ilmenite, $18 \%$ in crude ore, in ground & 98.0 \\
\hline 131 & $\mathrm{TiO}_{2}, 54 \%$ in ilmenite, $2.6 \%$ in crude ore, in ground & 98.0 \\
\hline 132 & $\mathrm{TiO}_{2}, 95 \%$ in rutile, $0.40 \%$ in crude ore, in ground & 98.0 \\
\hline 133 & Ulexite, in ground & 1.0 \\
\hline 134 & Uranium, in ground & $17,000.0$ \\
\hline 135 & Vermiculite, in ground & 1.0 \\
\hline 136 & Volume occupied, final repository for low-active radioactive waste & 0.0 \\
\hline 137 & Volume occupied, final repository for radioactive waste & 0.0 \\
\hline 138 & Volume occupied, underground deposit & 0.0 \\
\hline 139 & Zinc, $9.0 \%$ in sulfide, $\mathrm{Zn} 5.3 \%, \mathrm{~Pb}, \mathrm{Ag}, \mathrm{Cd}$, In, in ground & 16.0 \\
\hline 140 & Zinc, $\mathrm{Zn} 0.63 \%$, Au 9.7E- $4 \%$, Ag 9.7E- $4 \%$, Cu $0.38 \%, \mathrm{~Pb} 0.014 \%$, in ore, in ground & 16.0 \\
\hline 141 & Zinc, $\mathrm{Zn} 3.1 \%$, in mixed ore, in ground & 16.0 \\
\hline 142 & Zirconia, as baddeleyite, in ground & 1.0 \\
\hline 143 & Zirconium, $50 \%$ in zircon, $0.39 \%$ in crude ore, in ground & 53.0 \\
\hline
\end{tabular}




\section{References}

1. UN (Ed.) Transformation of Our World: Agenda 2030 on Sustainable Development; A/RES/70/1; United Nations: New York, NY, USA, 2015.

2. Bringezu, S.; Potočnik, J.; Schandl, H.; Lu, Y.; Ramaswami, A.; Swilling, M.; Suh, S. Multi-Scale Governance of Sustainable Natural Resource Use-Challenges and Opportunities for Monitoring and Institutional Development at the National and Global Level. Sustainability 2016, 8, 778. [CrossRef]

3. G20 Group of Twenty (Ed.) Leaders' Declaration. Shaping an Interconnected World; Munk School of Global Affairs \& Public Policy: Hamburg, Germany, 2017.

4. OECD Organisation for Economic Co-Operation and Development (Ed.) Policy Guidance on Resource Efficiency; OECD Publishing: Paris, France, 2016.

5. EU European Union (Ed.) Communication from the Commission to the European Parliament, the Council, the European Economic and Social Committee and the Committee of the Regions. Roadmap to a Resource Efficient Europe; COM(2011) 571; European Union: Brussel, Belgium, 2011.

6. O’Brien, M.; Hartwig, F.; Schanes, K.; Kammerlander, M.; Omann, I.; Wilts, H. Living within the safe operating space. A vision for a resource efficient Europe. Eur. J. Futures Res. 2014, 2. [CrossRef]

7. Sonderegger, T.; Dewulf, J.; Fantke, P.; Souza, D.M.; Pfister, S.; Stoessel, F.; Vieira, M.; Weidema, B.; Hellweg, S. Towards harmonizing natural resources as an area of protection in life cycle impact assessment. Int. J. Life Cycle Assess. 2017, 22, 1912-1927. [CrossRef]

8. Krausmann, F.; Gingrich, S.; Eisenmenger, N.; Erb, K.-H.; Haberl, H.; Fischer-Kowalski, M. Growth in global materials use, GDP and population during the 20th century. Ecol. Econ. 2009, 68, 2696-2705. [CrossRef]

9. Bringezu, S.; Ramaswami, A.; Schandl, H.; O’Brien, M.; Pelton, R.; Acquatella, J.; Ayuk, E.; Chiu, A.; Flanegin, R.; Fry, J.; et al. Assessing Global Resource Use: A Systems Approach to Resource Efficiency and Pollution Reduction; A Report of the International Resource Panel; IRP, Ed.; United Nations Environment Programme: Paris, France, 2017.

10. Bringezu, S. Possible Target Corridor for Sustainable Use of Global Material Resources. Resources 2015, 4, 25-54. [CrossRef]

11. Schandl, H.; Fischer-Kowalski, M.; West, J.; Giljum, S.; Dittrich, M.; Eisenmenger, N.; Geschke, A.; Lieber, M.; Wieland, H.; Schaffartzik, A.; et al. Global Material Flows and Resource Productivity. An Assessment Study of the UNEP International Resource Panel; United Nations Environment Programme: Paris, France, 2016.

12. German Federal Government (Ed.) Perspektiven für Deutschland. Unsere Strategie für eine Nachhaltige Entwicklung; German Federal Government: Berlin, Germany, 2002.

13. BMUB Federal Ministry for the Environment, Nature Conservation, Building and Nuclear Safety (Ed.) German Resource Efficiency Programme (ProgRess) Programme for the Sustainable Use and Conservation of Natural Resources; BMUB Federal Ministry for the Environment, Nature Conservation, Building and Nuclear Safety: Berlin, Germany, 2012.

14. BMUB Federal Ministry for the Environment, Nature Conservation, Building and Nuclear Safety (Ed.) German Resource Efficiency Programme II-Programme for the Sustainable Use and Conservation of Natural Resources; BMUB Federal Ministry for the Environment, Nature Conservation, Building and Nuclear Safety: Berlin, Germany, 2016.

15. Eurostat (Ed.) Economy-Wide Material Flow Accounts and Derived Indicators: A Methodological Guide; Eurostat, European Commission, Office for Official Publications of the European Communities: Luxembourg, 2001.

16. Eurostat (Ed.) Economy-Wide Material Flow Accounts HANDBOOK; Eurostat, European Commission, Office for Official Publications of the European Communities: Luxembourg, 2018. [CrossRef]

17. OECD Organisation for Economic Co-Operation and Development (Ed.) Measuring Material Flows and Resource Productivity: Volume 1. The OECD Guide; OECD Publishing: Paris, France, 2008.

18. Fischer-Kowalski, M.; Krausmann, F.; Giljum, S.; Lutter, S.; Mayer, A.; Bringezu, S.; Moriguchi, Y.; Schütz, H.; Schandl, H.; Weisz, H. Methodology and indicators of economy-wide material flow accounting: State of the art and reliability across sources. J. Ind. Ecol. 2011, 15, 855-876. [CrossRef]

19. Wang, H.; Yue, Q.; Lu, Z.; Schuetz, H.; Bringezu, S. Total Material Requirement of Growing China: 1995-2008. Resources 2013, 2, 270-285. [CrossRef]

20. Bringezu, S.; Schütz, H.; Moll, S. Rationale for and Interpretation of Economy-Wide Materials Flow Analysis and Derived Indicators. J. Ind. Ecol. 2003, 7, 43-64. [CrossRef] 
21. Schmidt-Bleek, F. Wieviel Umwelt Braucht der Mensch? Mips Das Maß für ökologisches Wirtschaften; Birkhäuser: Berlin, Germany, 1994; ISBN 3-7643-2959-9.

22. Saurat, M.; Ritthoff, M. Calculating MIPS 2.0. Resources 2013, 2, 581-607. [CrossRef]

23. Lettenmeier, M.; Rohn, H.; Liedtke, C.; Schmidt-Bleek, F. Resource Productivity in 7 Steps; How to Develop Eco-Innovative Products and Services and Improve Their Material Footprint; Wuppertal Institute for Climate, Environment and Energy: Wuppertal, Germany, 2009.

24. Wiesen, K.; Wirges, M. From cumulated energy demand to cumulated raw material demand. The material footprint as a sum parameter in life cycle assessment. Energy Sustain. Soc. 2017, 7. [CrossRef]

25. VDI (Ed.) VDI 4800: Part 2, Resource Efficiency: Evaluation of Raw Material Demand; Beuth: Berlin, Germany, 2018.

26. Huijbregts, M.A.J.; Hellweg, S.; Frischknecht, R.; Hendriks, H.W.M.; Hungerbuhler, K.; Hendriks, A.J. Cumulative energy demand as predictor for the environmental burden of commodity production. Environ. Sci. Technol. 2010, 44, 2189-2196. [CrossRef] [PubMed]

27. VDI (Ed.) VDI 4600: Part 1, Cumulative Energy Demand (KEA): Terms, Definitions, Methods of Calculation; Beuth: Berlin, Germany, 2012.

28. DIN EN ISO. Environmental Management_Life Cycle Assessment_Requirements and Guidelines (ISO: 14044:2006); International Organization for Standardization: Geneva, Switzerland, 2006.

29. Steinmann, Z.J.N.; Schipper, A.M.; Hauck, M.; Huijbregts, M.A.J. How Many Environmental Impact Indicators Are Needed in the Evaluation of Product Life Cycles? Environ. Sci. Technol. 2016, 50, 3913-3919. [CrossRef] [PubMed]

30. Schmidt-Bleek, F.; Bringezu, S.; Hinterberger, F.; Liedtke, C.; Spangenberg, J.; Stiller, H.; Welfens, M.J. MAIA Einführung in die Material-Intensitäts-Analyse nach dem MIPS-Konzept; Birkhäuser Verlag: Basel, Switzerland, 1998.

31. Althaus, H.-J.; Classen, M. Life Cycle Inventories of Metals and Methodological Aspects of Inventorying Material Resources in ecoinvent. Int. J. Life Cycle Assess. 2005, 10, 43-49. [CrossRef]

32. Krauss, U.; Wagner, H.; Mori, G. BGR Bundesanstalt für Geowissenschaften und Rohstoffe. In Stoffmengenflüsse und Energiebedarf bei der Gewinnung Ausgewählter Mineralischer Rohstoffe; Schweizerbart: Stuttgart, Germany, 1999; ISBN 3-510-95831-4.

33. Wiesen, K.; Saurat, M.; Lettenmeier, M. Calculating Material Input per Service Unit using the Ecoinvent database. Int. J. Perform. Eng. 2014, 10, 357-366.

34. Schoer, K.; Giegrich, J.; Kovanda, J.; Lauwigi, C.; Liebich, A.; Buyny, S.; Matthias, J. Conversion of European Productflows into Raw Material Equivalents. Final Report of the Project: Assistance in the Development and Maintenance of Raw Material Equivalents Conversion Factors and Calculation of RMC Time Series; IFEU: Heidelberg, Germany, 2012.

35. VDI (Ed.) VDI 4800: Part 1, Resource Efficiency: Methodological Principles and Strategies; Beuth: Berlin, Germany, 2016.

36. RMG Raw Materials Group. Mining Database (SEP Global Market Intelligence); RMG Raw Materials Group: Stockholm, Sweden, 2014.

37. World Bank (Ed.) World Bank Commodity Price Data (The Pink Sheet); World Bank: Washington, DC, USA, 2016.

38. WU Vienna. Global Material Flows Database. Factors Unused Extraction; WU Vienna: Vienna, Austria, 2016.

39. Winter, S.; Emara, Y.; Ciroth, A.; Su, C.; Srocka, M. openLCA 1.4, Comprehensive User Manual; Software Version: 1.4.1.; GreenDelta: Berlin, Germany, 2015.

40. Hoppe, W.; Thonemann, N.; Bringezu, S. Life Cycle Assessment of Carbon Dioxide-Based Production of Methane and Methanol and Derived Polymers. J. Ind. Ecol. 2018, 22, 327-340. [CrossRef]

41. Mostert, C.; Ostrander, B.; Bringezu, S.; Kneiske, T.M. Comparing Electrical Energy Storage Technologies Regarding Their Material and Carbon Footprint. Energies 2018, 11, 3386. [CrossRef]

42. Sameer, H.; Bringezu, S. Life cycle input indicators of material resource use for enhancing sustainability assessment schemes of buildings. J. Build. Eng. 2019, 21, 230-242. [CrossRef]

43. Sameer, H.; Weber, V.; Mostert, C.; Bringezu, S.; Fehling, E.; Wetzel, A. Environmental Assessment of Ultra-High-Performance Concrete Using Carbon, Material, and Water Footprint. Materials 2019, $12,851$. [CrossRef] [PubMed] 
44. Rørbech, J.T.; Vadenbo, C.; Hellweg, S.; Astrup, T.F. Impact Assessment of Abiotic Resources in LCA: Quantitative Comparison of Selected Characterization Models. Environ. Sci. Technol. 2014, 48, 11072-11081. [CrossRef] [PubMed]

45. Guinée, J.B. (Ed.) Handbook on Life Cycle Assessment, Operational Guide to the ISO Standards; Kluwer Academic Publisher: Dordrecht, Germany, 2002.

46. Van Oers, L.; Guinée, J. The Abiotic Depletion Potential: Background, Updates, and Future. Resources $2016,5$. [CrossRef]

47. Swart, P.; Alvarenga, R.A.F.; Dewulf, J. Abiotic resource use. In Life Cycle Impact Assessment. LCA Compendium -The Complete World of Life Cycle Assessment; Hauschild, M., Huijbregts, M.A.J., Eds.; Springer: Berlin, Germany, 2015.

48. Ekins, P.; Hughes, N.; Brigenzu, S.; Arden Clark, C.; Fischer-Kowalski, M.; Graedel, T.; Hajer, M.; Hashimoto, S.; Hatfield-Dodds, S.; Havlik, P.; et al. Resource Efficiency: Potential and Economic Implications. A Report of the International Resource Panel; United Nations Environment Programme: Paris, France, 2017.

49. Schneider, L.; Bach, V.; Finkbeiner, M. LCA Perspectives for Resource Efficiency Assessment; Special Types of Life Cycle Assessment; LCA Compendium-The Complete World of Life Cycle Assessment; Finkbeiner, M., Ed.; Springer: Berlin, Germany, 2016.

(C) 2019 by the authors. Licensee MDPI, Basel, Switzerland. This article is an open access article distributed under the terms and conditions of the Creative Commons Attribution (CC BY) license (http://creativecommons.org/licenses/by/4.0/). 